\title{
Environmental Drivers of Holocene Forest Development in the Middle Atlas, Morocco
}

\author{
Jennifer F. E. Campbell ${ }^{1}$, William J. Fletcher ${ }^{1 *}$, Sebastien Joannin ${ }^{2}$, Philip D. Hughes ${ }^{1}$, \\ Mustapha Rhanem ${ }^{3}$ and Christoph Zielhofer ${ }^{4}$ \\ ${ }^{1}$ Department of Geography, School of Environment, Education and Development, University of Manchester, Manchester, \\ United Kingdom, ${ }^{2}$ Institut des Sciences de l'Evolution de Montpellier, UMR 5554 Centre National de la Recherche \\ Scientifique, Montpellier University, Montpellier, France, ${ }^{3}$ Unité de Botanique et Écologie Montagnarde, Faculté des \\ Sciences, Département de Biologie, Moulay Ismail University, Meknès, Morocco, ${ }^{4}$ Institute of Geography, Leipzig University, \\ Leipzig, Germany
}

\section{OPEN ACCESS}

Edited by:

Thomas Giesecke, University of Göttingen, Germany

Reviewed by:

Henry Lamb,

Aberystwyth University,

United Kingdom

Cesar Morales Del Molino, Université de Bordeaux, France

*Correspondence:

William J. Fletcher will.fletcher@manchester.ac.uk

Specialty section:

This article was submitted to

Paleoecology,

a section of the journal

Frontiers in Ecology and Evolution

Received: 27 July 2017 Accepted: 07 September 2017

Published: 27 September 2017

Citation:

Campbell JFE, Fletcher WJ, Joannin S, Hughes PD, Rhanem M and Zielhofer C (2017) Environmental

Drivers of Holocene Forest Development in the Middle Atlas,

Morocco. Front. Ecol. Evol. 5:113

doi: 10.3389/fevo.2017.00113
In semi-arid regions subject to rising temperatures and drought, palaeoecological insights into past vegetation dynamics under a range of boundary conditions are needed to develop our understanding of environmental responses to climatic changes. Here, we present a new high-resolution record of vegetation history and fire activity spanning the last 12,000 years from Lake Sidi Ali in the southern Middle Atlas Mountains, Morocco. The record is underpinned by a robust AMS radiocarbon and ${ }^{210} \mathrm{~Pb} /{ }^{137} \mathrm{Cs}$ chronology and multi-proxy approach allowing direct comparison of vegetation, hydroclimate, and catchment tracers. The record reveals the persistence of steppic landscapes until 10,340 cal yr BP, prevailing sclerophyll woodland with evergreen Quercus until 6,300 cal yr BP, predominance of montane conifers (Cedrus and Cupressaceae) until 1,300 cal yr BP with matorralization and increased fire activity from 4,320 cal yr BP, and major reduction of forest cover after $1,300 \mathrm{cal}$ yr BP. Detailed comparisons between the pollen record of Lake Sidi Ali (2,080 m a.s.l.) and previously published data from nearby Tigalmamine $(1,626 \mathrm{~m}$ a.s.I.) highlight common patterns of vegetation change in response to Holocene climatic and anthropogenic drivers, as well as local differences relating to elevation and bioclimate contrasts between the sites. Variability in evergreen Quercus and Cedrus at both sites supports a Holocene summer temperature maximum between 9,000 and 7,000 cal yr BP in contrast with previous large-scale pollen-based climate reconstructions, and furthermore indicates pervasive millennial temperature variability. Millennial-scale cooling episodes are inferred from Cedrus expansion around $10,200,8,200,6,100,4,500,3,000$, and 1,700 cal yr BP, and during the Little Ice Age (400 cal yr BP). A two-part trajectory of Late Holocene forest decline is evident, with gradual decline from 4,320 cal yr BP linked to synergism between pastoralism, increased fire and low winter rainfall, and a marked reduction from 1,300 cal yr BP, attributed to intensification of human activity around the Early Muslim conquest of Morocco. This trajectory, however, does not mask vegetation responses to millennial climate variability. The findings reveal the sensitive response of Middle Atlas forests to rapid climate changes and underscore the exposure of the montane forest ecosystems to future warming.

Keywords: palynology, vegetation history, Northwest Africa, Lake Sidi Ali, Tigalmamine, millennial-scale variability, microcharcoal, fire history 


\section{INTRODUCTION}

\section{Background and Rationale}

Northwest Africa is a key region for exploring changes in forest vegetation cover and composition in response to past climate changes. Future climate change projections highlight the exposure of Northwest Africa to increased heat and drought stress (Born et al., 2008; Diffenbaugh and Scherer, 2011; Lelieveld et al., 2016). This exposure underlines the need for understanding the resilience of keystone forest species such as Cedrus atlantica and the ecosystem functions they support (e.g., nutrient cycling, carbon sequestration, reducing soil erosion) in the face of global change (Parmesan, 2006; Dawson et al., 2011; Moritz and Agudo, 2013). The biological and bioclimatic diversity of the region, particularly as contained within the Atlas mountain ranges (Ozenda, 1975; Medail and Quezel, 1997), furthermore provides a valuable "test-bed" for understanding the wider response of
Mediterranean and semi-arid environments and ecosystems to climatic perturbations.

The Middle Atlas range in Morocco presents a diversity of perennial and seasonal wetlands suitable for palaeoecological analysis and represents a focal area of current research investigation. Pioneering palynological investigations at $\mathrm{Col} \mathrm{du}$ Zad (Reille, 1976) yielded the first insights into past changes in the vegetation cover of the Middle Atlas (Figure 1), including fluctuations in the local population of Cedrus atlantica during the last ca 3,000 calendar years before present (cal yr BP). Studies at Tigalmamine on a marginal core (Lamb et al., 1989) and deep lake core (Lamb and van der Kaars, 1995) contributed the first well constrained environmental reconstructions spanning the full Holocene, and highlighted a Holocene succession of environmental changes at the site including an Early Holocene transition from grasslands to evergreen Quercus forest and the subsequent Late Holocene establishment of Cedrus. The studies also supported fundamental insights into palaeoclimatic linkages

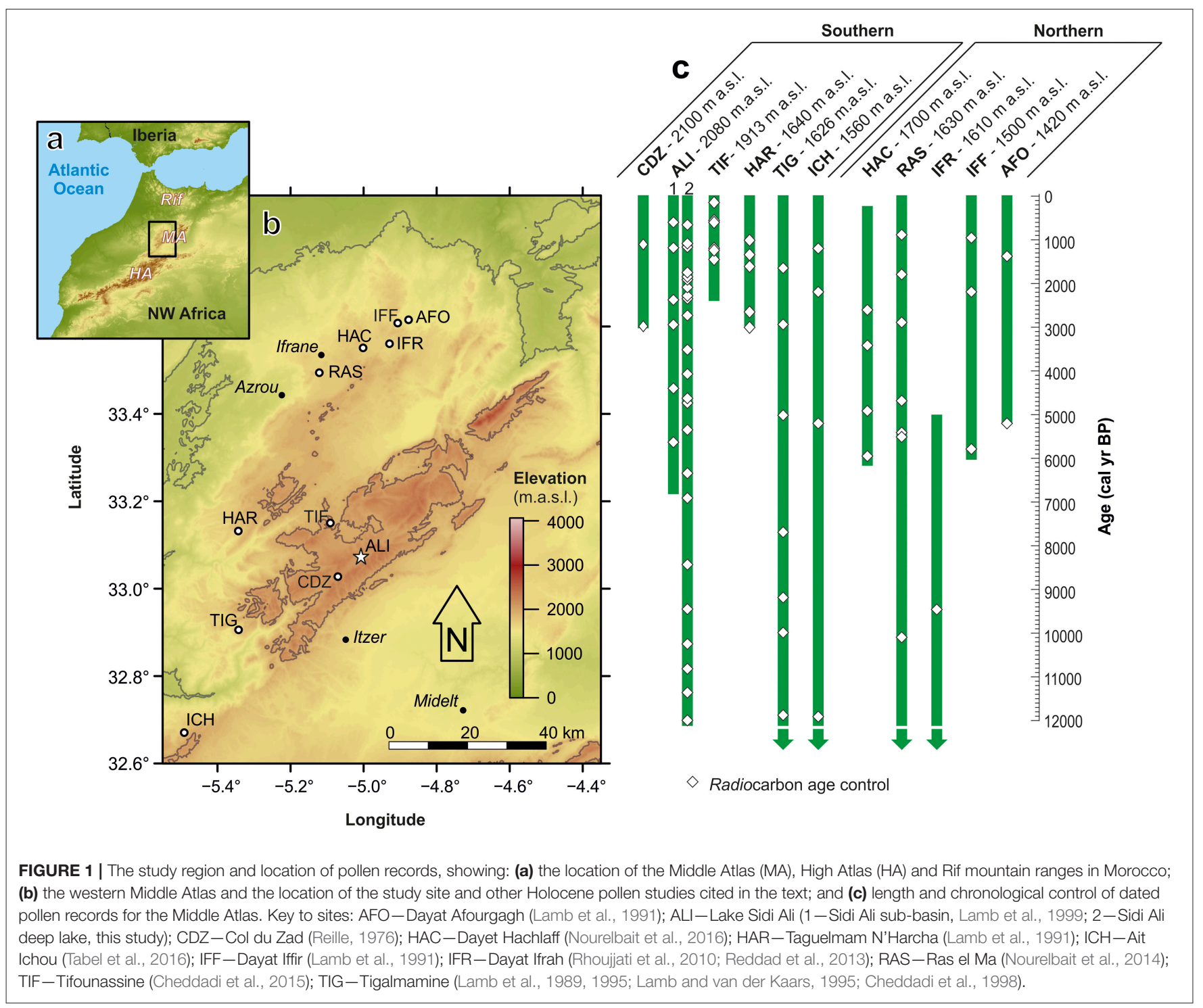


between Northwest Africa and the Atlantic region, linking lakelevel lowering in the Middle Atlas with North Atlantic cooling events (Lamb et al., 1995). Alongside palaeoclimatic insights, key information emerged about the scale and nature of human impacts, through the complementary study of Holocene deposits at Taguelmam N'Harcha, Dayat Iffir, and Dayat Afoughagh (Lamb et al., 1991). The studies indicate a history of low intensity human impact on the Middle Atlas landscape during the last five millennia, intensification of impacts around 2,000 cal yr BP and a significant reduction of Cedrus populations at Taguelmam N'Harcha at 1,400 cal yr BP. A 7,000 cal yr record from Lake Sidi Ali (Lamb et al., 1999) adopted a multiproxy approach and examined interactions between climate, catchment processes and lake status associated with the transition from evergreen Quercusto Cedrus- dominated forest and subsequent forest decline during the last 3,000 cal yr.

The Middle Atlas has recently experienced a resurgence of palaeoecological activity, including contributions to the understanding of longer term environmental change since the last glacial including past fire activity at Lake Ifrah (Rhoujjati et al., 2010; Reddad et al., 2013), although the core does not include the last 5,000 years. Recent studies have contributed further knowledge regarding patterns and processes of Holocene vegetation change in the northwestern Middle Atlas at Ras el Ma and Dayat Hachlaf (Nourelbait et al., 2014, 2016; Tabel et al., 2016), and forthcoming data for the Holocene are indicated for Lake Tifounassine (Cheddadi et al., 2015). At Dayat Hachlaf, forested conditions with Quercus (undifferentiated) and Pinus are recorded throughout the record from 6,000 cal yr BP, and include a shift in forest composition around 3,500 cal yr BP, with the expansion of Cedrus (Nourelbait et al., 2016). In contrast, the nearby record of Ras el Ma documents a late development of forest with Quercus and Cedrus only after 5,000 cal yr BP (Nourelbait et al., 2014). In the southwestern Middle Atlas, the pollen record of Ait Ichou documents the transition from steppic to forested vegetation at 6,800 cal yr BP (Tabel et al., 2016). Comparison of Late Holocene records from the Middle Atlas and Rif support similar trajectories of increasing human impact during the last 2,000 years (Cheddadi et al., 2015). Overall, the growing number of studies from the Middle Atlas highlight important spatial and temporal variability in the patterns of forest development, and point to multiple drivers of environmental change (climate, human activity, fire).

In light of the available information, key research areas regarding the dynamics of montane vegetation in the Middle Atlas require further investigation and are highly relevant in the context of future climate change. These include:

(i) The nature and timing of vegetation changes during the Holocene, including spatial and altitudinal patterns in the forest cover and composition;

(ii) The exposure of forest ecosystems to long-term and rapid climate changes of the Holocene (e.g., Mayewski et al., 2004) and/or resilience in the face of climatic perturbation (Aranbarri et al., 2014); (iii) The spatiotemporal characteristics of Holocene fire regimes and the role of fire as an agent of Holocene vegetation change;

(iv) The role of human agency in Holocene land cover changes, the resilience of the natural vegetation cover, and humanenvironment interactions (Blondel, 2006).

Ultimately, robust exploration of these research areas requires palaeoecological data with high temporal resolution (centennialscale sampling or better), robust radiometric chronological control, and, ideally, a multi-proxy approach with co-registration of independent climate tracers in the same cores.

The focus of this study is Aguelmam (Lake) Sidi Ali. As the largest and deepest perennial lake in the Middle Atlas, the site offers great potential for addressing key regional palaeoenvironmental and palaeoclimatic questions. The first coring efforts at the site focused on a marginal sub-basin, yielding a sediment record spanning the last ca. 7,000 cal yr BP (Barker et al., 1994; Lamb et al., 1999). These previous studies reveal signals of recurrent centennial-scale water-level fluctuations in the diatom assemblages (Barker et al., 1994), and long-term catchment impacts on lake status linked to vegetation change and human impact (Lamb et al., 1999). The studies clearly highlight the merits of a multiproxy palaeolimnological approach (Birks and Birks, 2006), and also provide first indications of some of the particular challenges at Lake Sidi Ali, notably for radiocarbon dating in the hardwater karstic setting, for disentangling climate and catchment influences on the lake system, and for elucidating climatic and anthropogenic drivers of change.

New research activity at Lake Sidi Ali since 2012 has focused on drilling of the main (deep) lake basin, recovery of longer cores extending across the full Holocene, and development of a robust radiometric deposition model (Fletcher et al., 2017). Reliance on ${ }^{210} \mathrm{~Pb} /{ }^{137} \mathrm{Cs}$ analysis and 26 AMS radiocarbon dates on terrestrial pollen concentrates and macrofossils circumvents the problem of hardwater errors for bulk radiocarbon dates (Fletcher et al., 2017) and underpins the high-resolution and multiproxy palaeolimnological study (Zielhofer et al., 2017a). Key findings include the detection of pervasive variability in Atlanticderived winter precipitation, and a Mid Holocene shift in prevailing climate pattern reflecting the emergence of centennial dynamics resembling the North Atlantic Oscillation (NAO-like) after 5,000 cal yr BP (Zielhofer et al., 2017a). The main horizon of anthropogenic catchment disturbance is also constrained by geochemical and sedimentological data to 1,400 cal yr BP (Zielhofer et al., 2017a), and is supported by evidence for a relatively old, soil-derived pollen component in some dating samples (Fletcher et al., 2017). New research also reveals that Lake Sidi Ali acts as a receptor for remote (Saharan) dust, providing indications of millennial-scale fluctuations in dust mobilization across the end of the African Humid Period (Zielhofer et al., 2017b). Overall, this context provides an ideal opportunity to evaluate vegetation dynamics on a range of timescales (orbital, millennial, centennial), and to test the coupling of vegetation and hydroclimate proxies. 
Here, we present a new record of vegetation and fire activity from Lake Sidi Ali in the Middle Atlas with subcentennial resolution (60 year average), and undertake a detailed comparison with the deep lake record of Tigalmamine (Lamb and van der Kaars, 1995), the only other full Holocene pollen record in the Middle Atlas with a comparable (110 year average) sampling resolution as well as robust age control incorporating correction for hardwater errors. Specifically, we seek to address several key questions about the environmental drivers of vegetation change in the Middle Atlas. First, regarding vegetation-climate relationships, is there evidence for an Early Holocene summer temperature maximum consistent with insolation forcing and climate models (Renssen et al., 2009), or a cool Early Holocene, as suggested by large-scale pollenbased reconstructions for the Western Mediterranean (Davis et al., 2003; Mauri et al., 2015)? Is there evidence for vegetation response to millennial-scale variability in Holocene climate, as previously reported for the Western and Central Mediterranean (Fletcher et al., 2013; Jaouadi et al., 2016) but for which evidence is generally lacking in the Middle Atlas (cf. Lamb et al., 1995)? Second, regarding fire ecology in the Middle Atlas landscape, how did fire activity develop with respect to Holocene changes in climate, biomass, and human activity? Was fire activity at this high elevation site limited by fuel availability or climate (Linstädter and Zielhofer, 2010), and did constraints change through the Holocene in parallel with neighboring regions (Gil-Romera et al., 2010)? Finally, regarding the origins of the currently degraded forest landscape, was the trajectory of human impact gradual and multi-millennial (e.g., Tinner et al., 2013) or incremental, with distinct thresholds of major impact (e.g., Morales-Molino et al., 2017)? Moreover, did the transition to an anthropogenic landscape mask climate responses in the vegetation, or were impacts of pervasive Holocene climatic fluctuations and historical climate changes evident?

\section{Study Area}

The Middle Atlas range is an intracontinental fold-thrust belt that extends for around $250 \mathrm{~km}$ in northern Morocco along a primarily SW-NE alignment (Arboleya et al., 2004) and reaches elevations in excess of 3,300 m.a.s.l. in the eastern sector. The dominant geology of the Middle Atlas is Mesozoic limestones giving rise to significant karstification of the landscapes. A legacy of Plio-Pleistocene volcanism is also highly evident in regional landforms (De Waele and Melis, 2009). Located on one of the main regional SW-NE trending lineaments, Lake Sidi Ali $\left(33^{\circ} 03^{\prime}\right.$ $\mathrm{N}, 05^{\circ} 00^{\prime} \mathrm{W}$ ) is one of the largest (surface area of up to $2.8 \mathrm{~km}^{2}$ ), highest (2,080 m.a.s.l.) and deepest (up to $40 \mathrm{~m}$ water depth) lakes in the karstic uplands of the western Middle Atlas Mountains in Morocco. The lake is located within a small closed catchment $\left(\sim 14 \mathrm{~km}^{2}\right)$ that reaches up to around 2,400 m.a.s.l. in elevation. The lake lies in a structural depression at the contact between Middle Jurassic limestones and Lower Jurassic dolomites. In September 2012, the lake displayed a maximum water depth of $38 \mathrm{~m}$ and anaerobic conditions at the hypolimnion (Zielhofer et al., 2017a). A shallow sub-basin to the SW is partly separated from the main basin by early Quaternary basalt flows. The two basins are linked when lake levels are at their highest (Lamb et al.,
1999); they are currently separated due to lake lowering trends in recent decades (Menjour et al., 2016; Figure 2). There are no significant surface inlet or outlet streams, and lake levels are sensitive to annual precipitation variability (Sayad et al., 2011).

Located at the southern margins of the Middle Atlas, Lake Sidi Ali is situated near the transition between the Atlantic, Mediterranean and Saharan climatic zones (Knippertz et al., 2003; Born et al., 2010). The regional climate is Mediterranean with summer drought influenced by the sub-tropical highpressure belt and humid winters impacted by the Atlantic westerly circulation. Across the Middle Atlas, a strong NW to SE gradient of increasing aridity is evident, with high rainfall due to orographic effects at the NW margins of the Middle Atlas near Ifrane, and drying associated with subsequent Foehn effects as northwesterly air masses cross the SW-NE ridges of the Middle Atlas (Rhanem, 2009). The local climate station at Lake Sidi Ali documents a mean annual temperature of $10.3^{\circ} \mathrm{C}$, mean temperature of the coldest month (January) of $2.0^{\circ} \mathrm{C}$ and mean temperature of the warmest month (July) of $19.7^{\circ} \mathrm{C}$. A mean annual precipitation of $430 \mathrm{~mm}$ was recorded between 1982 and 2009, with maxima in spring (April-May) and late autumn/winter (November-December), as well as torrential summer storms associated with convection along the AtlasSahara margins.

The vegetation of the Middle Atlas displays a characteristic series of altitudinal vegetation levels associated with temperature and moisture availability across the thermo- to oromediterranean bioclimates (Benabid, 1982; Figure 3). The current forest vegetation surrounding Lake Sidi Ali corresponds to the high-altitude, semi-arid Cedrus series (Achhal et al., 1980) with Cedrus atlantica (Endl.) Manetti ex Carrière, Quercus rotundifolia Lam. (synonym Quercus ilex. subsp. ballota (Desf.) Samp.), Juniperus thurifera L., Crataegus sp., Acer monspessulanum L. and Fraxinus dimorpha Coss. and Durieu accompanied by Berberis sp., Ribes uva-crispa L., and Ephedra major Host on locally rocky substrates (Figure 3). The forest surrounding the lake is rather sparse and degraded, and has an open character that gives way to scrub with spiny, cushion-form xerophytes (primarily Fabaceae spp.), along with an array of herbaceous taxa, including Asteraceae spp., Brassicaceae spp., Plantago spp., and Rumex spp. In common with many areas across its Maghrebian range (Linares et al., 2012), Cedrus atlantica trees near the site show signs of degradation (logging, grazing pressure, and cutting for firewood) and die-back (loss of foliage, crown dieback, mortality) (Figure 4).

Tigalmamine $\left(32^{\circ} 54^{\prime} \mathrm{N} 05^{\circ} 21^{\prime} \mathrm{W}, 1,626 \mathrm{~m}\right.$ a.s.l. $)$, studied by Lamb and van der Kaars (1995) and a source of secondary data for this study, is part of a cluster of lakes located ca. $50 \mathrm{~km}$ to the southwest of Lake Sidi Ali and $450 \mathrm{~m}$ lower in elevation. The study site was $0.6 \mathrm{~km}^{2}$ in area and around $16 \mathrm{~m}$ water depth at the date of coring, with an above ground catchment area of $\sim 3.5 \mathrm{~km}^{2}$ (Lamb and van der Kaars, 1995). Tigalmamine experiences a similar temperature regime to Lake Sidi Ali (mean $10^{\circ} \mathrm{C}$, mean temperature of the coldest month (January) of $2.5^{\circ} \mathrm{C}$ and mean temperature of the warmest month (July) of $20^{\circ} \mathrm{C}$ ) and significantly higher rainfall $(930 \mathrm{~mm} / \mathrm{yr})$ (Cheddadi et al., 1998). The surrounding forest vegetation is characteristic of the 


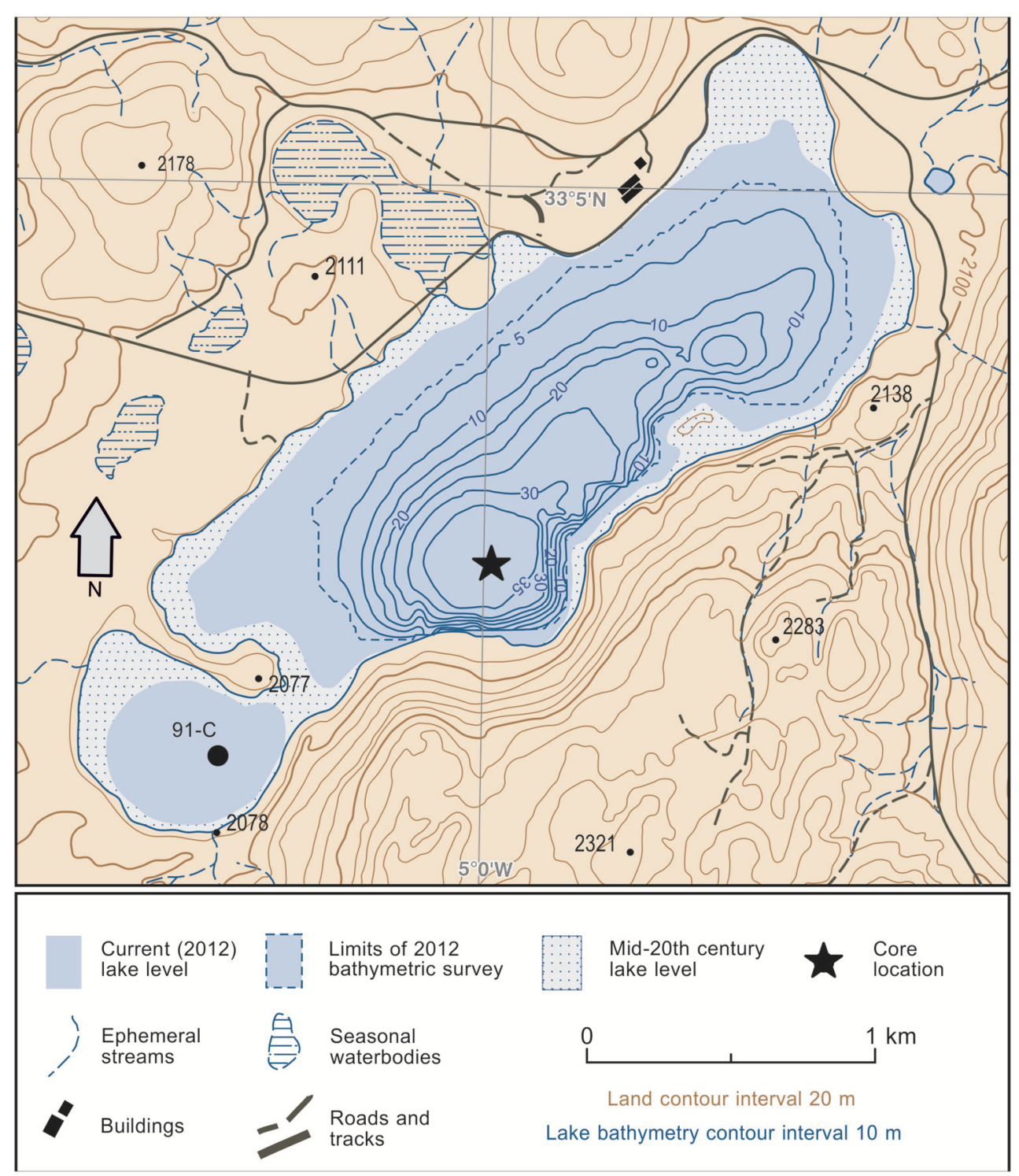

FIGURE 2 | Topographic setting and bathymetry of Lake Sidi Ali, showing the drilling position of core sequence ALI 01-10 (Zielhofer et al., 2017a and this study) and core 91-C (Barker et al., 1994; Lamb et al., 1999).

upper mediterranean level (Figure 3), dominated by Quercus rotundifolia with Quercus canariensis Willd. and Cedrus atlantica along with Ilex aquifolium L. and Crataegus spp. (Lamb et al., 1989).

\section{MATERIALS AND METHODS}

Sediment cores were recovered at Lake Sidi Ali from a floating platform located at the deepest part of the main lake basin (Figure 2) using a UWITEC piston corer with plastic liners. A $19.56 \mathrm{~m}$ core (ALI 01-10) was recovered in 10 drives from a single borehole. Careful measurement on the steel depth cable was used to control the depth of the 10 sequential drives. A core-catcher device prevents material from falling out of the core chamber. Total depth of the borehole was determined by the capability of the equipment, and does not represent the base of the sediment infill of the lake. The reported depths represent a corrected depth scale that accounts for core expansion in the liners. Full details of the bathymetric and seismic surveys and coring procedure are given in Zielhofer et al. (2017a).

The ALI 01-10 cores comprise horizontally bedded, faintly laminated, calcareous to lime silicic gyttja without any hiatus or major sedimentological shifts (Figure 5). Due to rare terrestrial macrofossils in the core, a dating strategy focusing on systematic AMS radiocarbon dating of pollen concentrates was implemented (Fletcher et al., 2017). Dates on pollen concentrates $(n=23)$, terrestrial macrofossils $(n=3)$ and ${ }^{210} \mathrm{~Pb} /{ }^{137} \mathrm{Cs}$ 


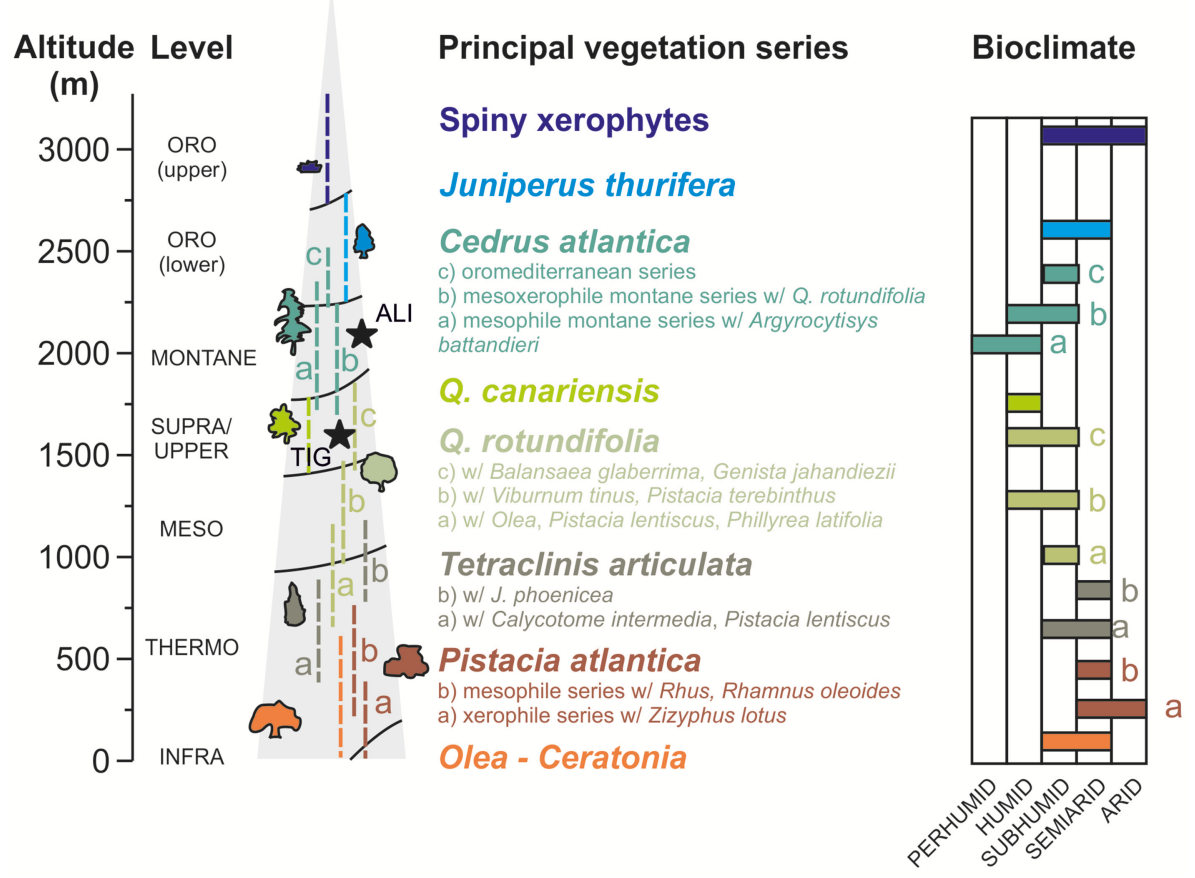

FIGURE 3 | Altitudinal distribution of the principal vegetation series of the Middle Atlas and their associated bioclimates, derived from Benabid (1982), showing the position of Lake Sidi Ali (ALI) and Tigalmamine (TIG).

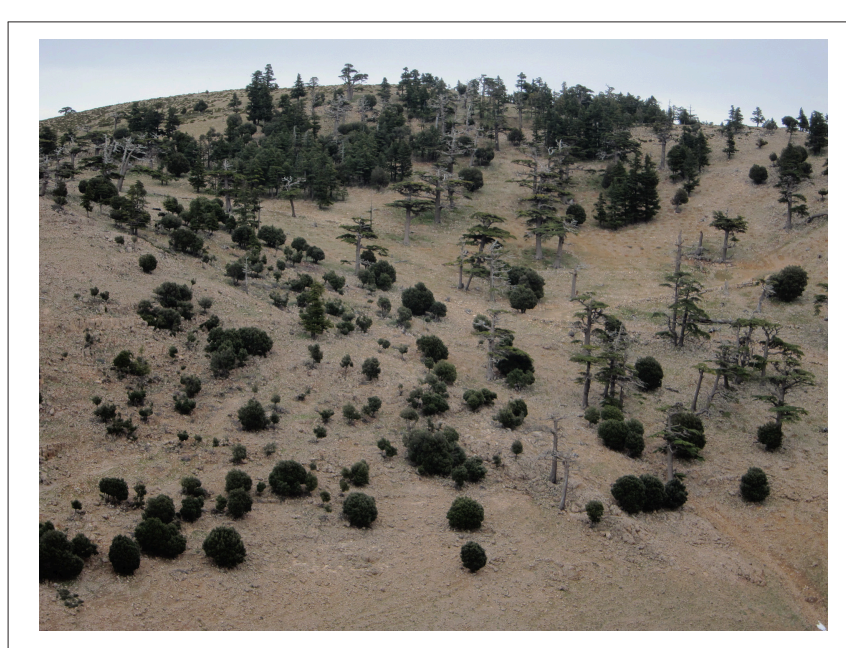

FIGURE 4 | Vegetation cover in the Lake Sidi Ali catchment in 2014. Cedrus atlantica trees showing signs of crown and/or branch dieback as well as dead individuals are common, interspersed with young healthy specimens of Quercus rotundifolia. (Credit: W. Fletcher).

constraints on the upper sediments were used to generate a realistic Poisson-process Bayesian deposition model (Bronk Ramsey, 2008; Figure 5). The deposition interval spans the last $12,000 \mathrm{cal}$ yr BP. Long-term average sedimentation rates at this deep-lake location exceed $0.15 \mathrm{~cm} / \mathrm{yr}(1.5 \mathrm{~m} / \mathrm{ka})$, offering great potential for high resolution proxy analysis spanning the entire Holocene.
Volumetric $1 \mathrm{~cm}^{3}$ samples were prepared for pollen analysis at regular, $10 \mathrm{~cm}$ intervals, yielding a total of 201 samples and an average temporal resolution of 60 years. A series of standard preparation treatments were employed, specifically: (i) addition of Lycopodium tablets to enable the calculation of pollen concentrations (Stockmarr, 1971); (ii) $\mathrm{KOH}$ digestion to remove humid acids; (iii) sieving at $180 \mu \mathrm{m}$ to remove coarse material; (iv) removal of siliceous material using either HF digestion or dense-media separation with sodium polytungstate (SPT); and (v) acetolysis to destroy cellulose. At stage (iv) SPT was selectively applied to improve concentration of organic material in the upper part of the sequence, following rigorous testing to ensure that no bias is imparted in terms of pollen type recovery (Campbell et al., 2016). Residues were dehydrated in alcohol and mounted using silicon oil. A minimum of 300 terrestrial grains were counted for each sample using transmitted light microscopy at high magnification (400-1,000x). Non-pollen palynomorphs (NPPs) observed during the pollen counts were recorded. Pollen taxa were identified with reference to pollen atlases and keys (Moore et al., 1991; Reille, 1992; Beug, 2004). Lygeum spartum is an unusual example of a single species within the Poaceae family that is easily distinguished due to its large size (longest dimension 50-70 $\mu \mathrm{m}$ ), elongated elliptical/ovoid form (length/width ratio $>2$ ) and lateral pore position (Giner et al., 2002; AbdeddaimBoughanmi and Kaid-Harche, 2009).

Pollen percentages are calculated on the basis of a main sum of total land pollen (TLP) excluding aquatics and spores. Percentages of aquatic pollen and spores are expressed on the basis of the main sum of TLP plus the individual 


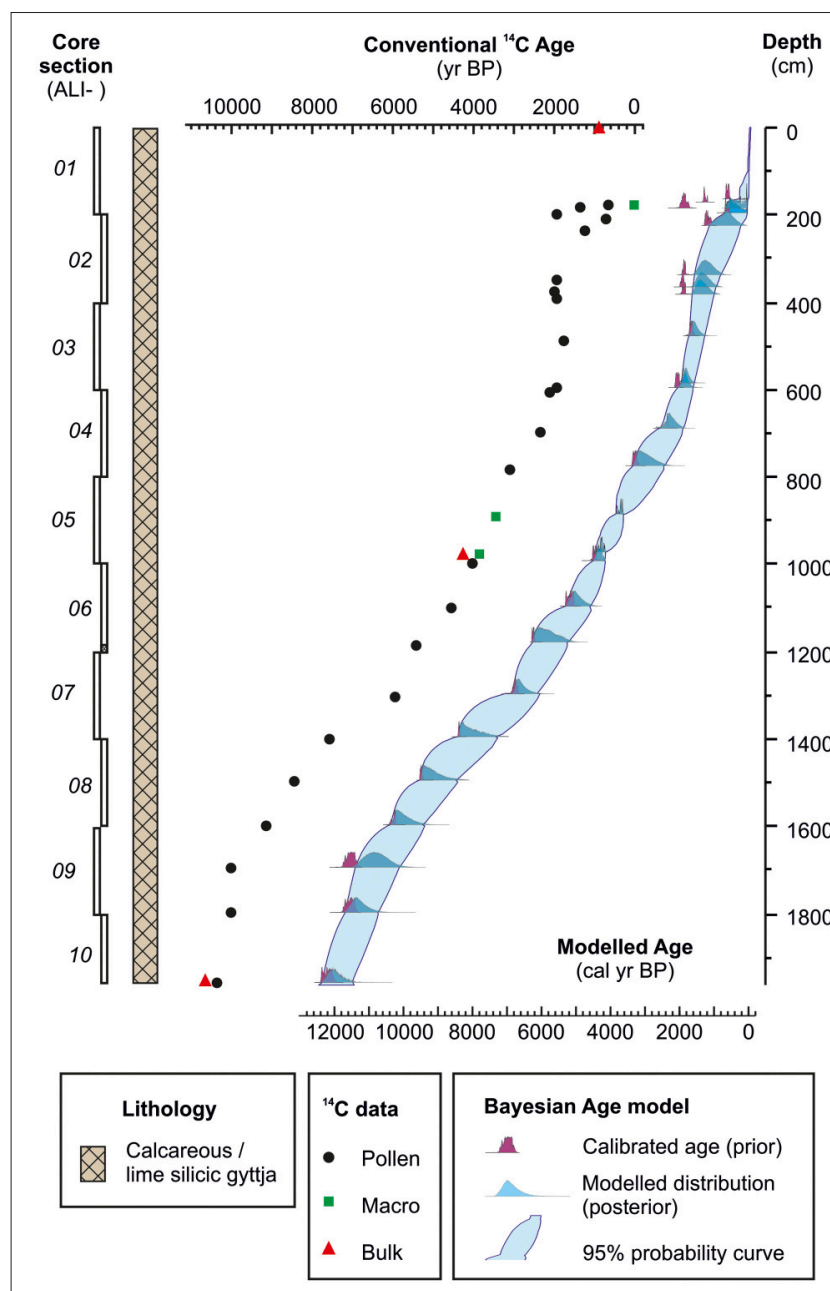

FIGURE 5 | Core sequence ALI 01-10, lithology, radiocarbon control points and Bayesian deposition model for Lake Sidi Ali (full details of the age model in Fletcher et al., 2017).

pollen/spore count. Pollen assemblage zones (PAZs) are defined based on changes in the TLP percentages, with a hierarchical division of major PAZs reflecting higher order shifts in dominant taxa and sub-zones reflecting lower order fluctuations in the pollen spectra. The PAZs were determined by numerical zonation by optimal splitting by information content (Bennett, 1996) including twenty-two taxa occurring at $>3 \%$ in at least one sample (Acer, Apiaceae, Artemisia, Astragalus type, Brassicaceae, Caryophyllaceae, Cedrus, Chenopodiaceae, Coronilla type, Cupressaceae, deciduous Quercus, Ephedra, evergreen Quercus, Fraxinus, Olea, Phillyrea, Pinus, Pistacia, Plantago, Poaceae, Rumex, Ulex type). Statistically significant PAZs exceeding a broken-stick model were retained (Bennett, 1996). Sub-zones were subsequently selected by eye so as to best facilitate the description of the pollen record. The arboreal/non-arboreal (AP/NAP) pollen ratio was also calculated as a proxy for forest cover that is not constrained by the limitations of closed percentage data (Magri, 1994).
In addition to pollen percentages, pollen concentration and pollen accumulation rates (PARs, expressed as grains $\mathrm{cm}^{-2}$ $\mathrm{yr}^{-1}$ ) were calculated. PARs are a useful tool for understanding the behavior of individual taxa, while avoiding the classical problem of interdependence of percentage abundance values (Jensen et al., 2007). The PAR for each taxon is independent of other taxa within the record, and therefore may provide a better representation of the local abundance of the individual taxa (Seppä and Hicks, 2006).

Taxon-specific concentrations $\left(\mathrm{X}_{\mathrm{C}}\right.$, expressed in grains . $\mathrm{cm}^{-3}$ ) were calculated as follows:

$$
\mathrm{X}_{\mathrm{C}}=\left(\mathrm{N}_{\mathrm{X}} \cdot \mathrm{T}_{\mathrm{L}}\right) /\left(\mathrm{N}_{\mathrm{L}} \cdot \mathrm{V}\right)
$$

Where $\mathrm{N}_{\mathrm{X}}$ is number of the individual taxon counted, $\mathrm{T}_{\mathrm{L}}$ is the number of Lycopodium added, $\mathrm{N}_{\mathrm{L}}$ is the number of Lycopodium counted, and $\mathrm{V}$ is the volume of the sample in $\mathrm{cm}^{3}$. PAR were subsequently calculated using the concentrations and sedimentation rates derived from the age-depth model:

$$
\mathrm{X}_{\mathrm{PAR}}=\mathrm{X}_{\mathrm{c}} \times \mathrm{SR}
$$

Where $\mathrm{X}_{\mathrm{PAR}}$ is the pollen accumulation rate of the taxa (expressed in grains $\cdot \mathrm{cm}^{-2} \mathrm{yr}^{-1}$ ), $\mathrm{X}_{\mathrm{c}}$ is the concentration of the taxa (in grains $\cdot \mathrm{cm}^{-3}$ ) and SR is the sedimentation rate (in $\mathrm{cm}$. $\left.\mathrm{yr}^{-1}\right)$.

Microscopic charcoal analysis was conducted on the same slides as the pollen analysis. A sum of 200 charcoal particles and Lycopodium spores was counted in each sample, to reach an accurate estimate of particles for the entire sample (Finsinger and Tinner, 2005). Charcoal concentration (CHAC) and accumulation rate (CHAR) are calculated in the same way as for pollen concentration and PAR.

Comparative pollen data for the central lake core C-86 at Tigalmamine (Lamb and van der Kaars, 1995) were downloaded from the European Pollen Database (EPD, Fyfe et al., 2009). We reproduce the published age model for C-86 using linear interpolation between the seven hardwater-corrected calcite dates (see Table 1 of Lamb and van der Kaars, 1995: 402) but recalibrate the corrected radiocarbon ages using the IntCal13 calibration curve (Reimer et al., 2013). Following Lamb and van der Kaars (1995), the dates on organic material are excluded as they may be subject to hardwater errors. Select pollen curves are reproduced graphically in this study from the pollen diagram of the Sidi Ali marginal basin core C-91 (Lamb et al., 1999). We harmonize the pollen nomenclature of these works with our own, equating Quercus rotundifolia with evergreen Quercus type, Quercus canariensis with deciduous Quercus type, and Gramineae with Poaceae.

To highlight millennial-scale trends, data for select curves from Lake Sidi Ali and Tigalmamine were resampled to a regular sample spacing of 60 years and a lowpass filter was applied at $1,000 \mathrm{yr}\left(T_{0} / T=0.06\right)$ using the statistics software PAST (Hammer et al., 2001). 


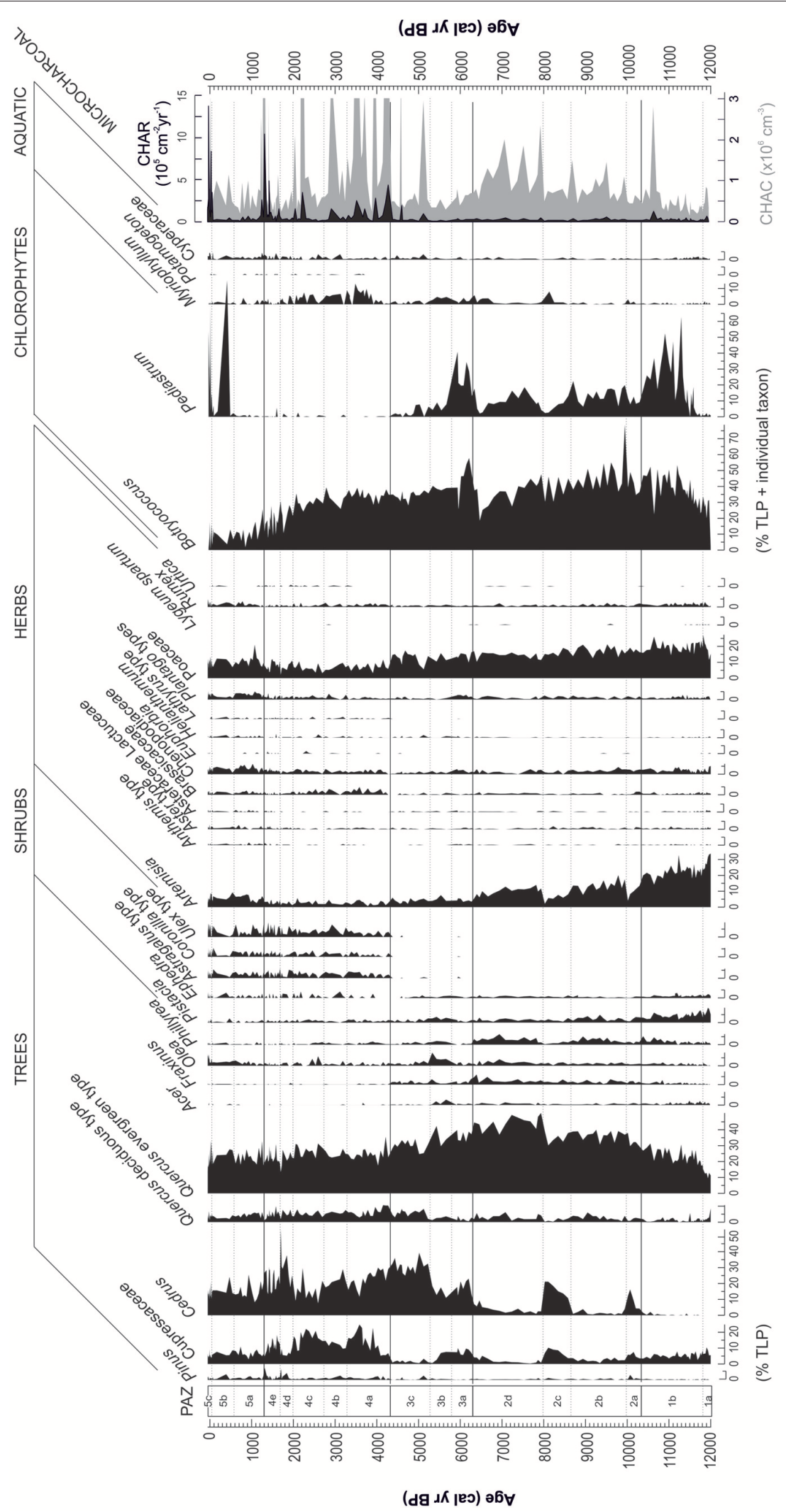

FIGURE 6 | Select pollen, NPPs and microcharcoal data from Lake Sidi Ali (cores ALI 01-10) plotted against age. Pollen percentages calculated against a main sum of total land pollen (TLP) which excludes aquatics and spores. 
TABLE 1 | Definition and main characteristics of the pollen assemblage zones (PAZs) (boldface) and sub-zones for cores ALI 01-10.

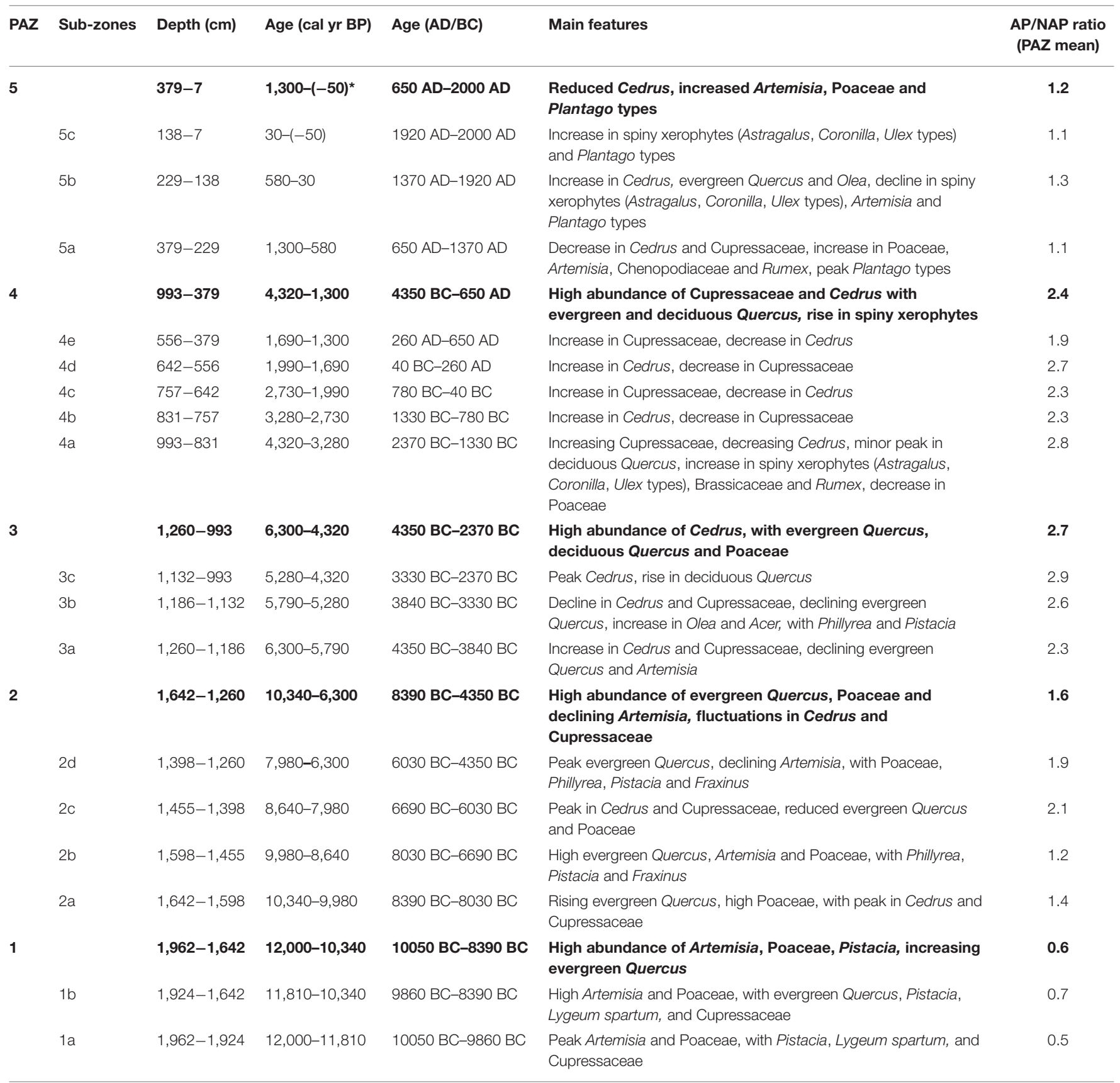

${ }^{*}$ Coretop defined as 2012 AD; uppermost sample modeled age -52.4 cal BP (2002 AD).

\section{RESULTS}

\section{Pollen}

Core ALI 01-10 contains well-preserved and abundant pollen. The dominant feature of the Holocene record is the longterm transition from herbaceous- to arboreal-dominated spectra associated with a succession of dominant pollen types (Artemisia, Poaceae, Quercus evergreen type, Cedrus, and Cupressaceae) across five major pollen assemblage zones (PAZ-1 to PAZ-5) and several sub-zones (Figure 6, Table 1). Pollen concentration values and PARs confirm the main changes in pollen percentages throughout the record (Figure 7). Specifically, high PARs support the following sequence of dominant pollen types: Artemisia and Poaceae (PAZ-1); Poaceae and evergreen Quercus, with episodic increases in Cedrus and Cupressaceae (PAZ-2); Cedrus (PAZ-3); Cedrus and Cupressaceae (PAZ-4); and finally a reduction in all woody taxa (PAZ-5). Alongside terrestrial pollen, chlorophyte algae (Botryococcus and Pediastrum) are abundant in some intervals, with high values for both taxa in PAZ-1b, PAZ-2, and PAZ-3, and spikes in Pediastrum abundance in PAZ-5. 


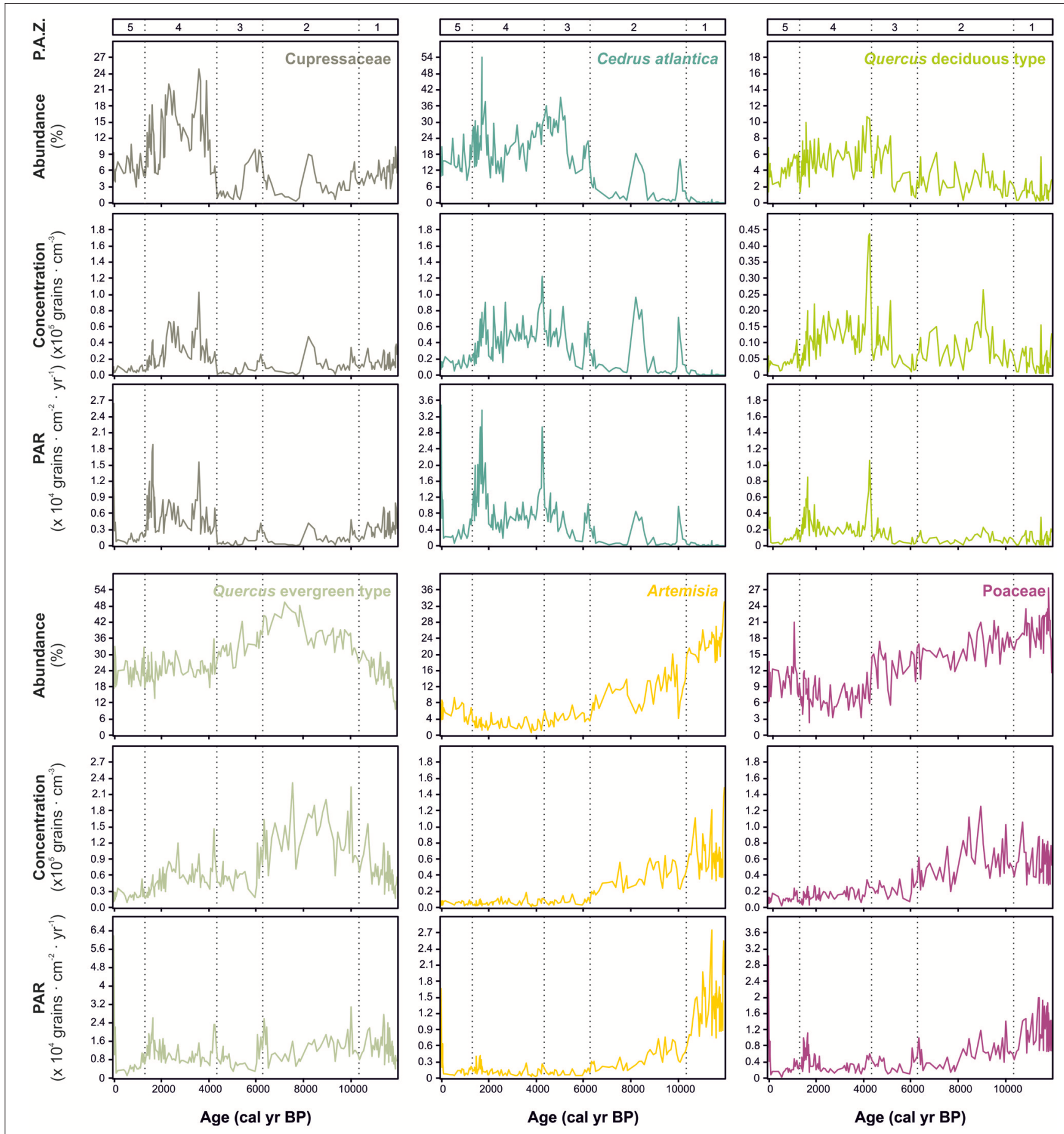

FIGURE 7 | Comparison of percentage, concentration and pollen accumulation rate (PAR) values for six main taxa at Lake Sidi Ali plotted against age with pollen assemblage zones (PAZs) indicated.

Only a modest assemblage of submerged (e.g., Myriophyllum) and marginal (e.g., Typha/Sparganium) aquatic pollen types is documented. Overall, pollen concentrations (typically $\sim 2 \times 10^{5}$ grains $\mathrm{cm}^{-3}$ ) and PARs (typically around $\sim 5 \times 10^{4}$ grain $\mathrm{cm}^{-2}$ $\mathrm{yr}^{-1}$ ) are high throughout the core.

\section{Microcharcoal}

Microcharcoal is recorded throughout the sequence and CHAC values vary between the PAZs, specifically: low in PAZ-1; moderate and fairly stable in PAZ-2; low in PAZ-3; high, dynamic, fluctuating in PAZ-4; low in PAZ-5, excluding a 
sub-recent peak (Figure 6). CHAR values, taking into account sedimentation rates, display low values in PAZ-1 to PAZ-3, and show the highest values in in PAZ-4 and PAZ-5.

\section{DISCUSSION}

\section{Vegetation Signals at Lake Sidi Ali}

Due to the large surface to catchment ratio and closed hydrological system at Lake Sidi Ali, the pollen signal should be dominated by a well-mixed atmospheric pollen rain without over-representation of local or lake-marginal vegetation, making it an ideal site to study regional vegetation responses to climate. Considering the size of the basin, it is anticipated that pollen will be recruited from long distances (up to $20 \mathrm{~km}$ ) (Prentice, 1985). Furthermore, upslope transport of pollen from lower elevations is typical of montane locations (Markgraf, 1980). This phenomenon is evident in modern surface pollen samples from the Lake Sidi Ali catchment (Bell and Fletcher, 2016), which contain taxa such as Olea, Phillyrea, and deciduous Quercus that grow at lower elevations in thermo-, meso-, and supra/upper-mediterranean bioclimates, respectively (Figure 3). The interpretation therefore considers that pollen source areas will be very large and will integrate signals across several altitudinal levels. High pollen concentrations and PARs may indicate focusing of organic matter into the deepest part of the lake (Figure 2). While the PARs provide valuable confirmation of the main vegetation changes, they may not necessarily be independent of lake level changes or represent true productivity values of surrounding vegetation (Giesecke and Fontana, 2008).

The new pollen data show excellent replication of the original pollen record of Lamb et al. (1999) allowing for some centennial-scale temporal offsets probably relating to the weaker chronological control on core 91-C (Figure 8). Three phases of Cedrus expansion are clearly recognized (Figure 8, shaded bars), as well as strong similarities in the curves for other important terrestrial (Artemisia, evergreen Quercus) and aquatic (Myriophyllum, Pediastrum) types. Some differences are noted; for example, higher abundances of Cupressaceae and deciduous Quercus are recorded in cores ALI 01-10, which may reflect differences in dominant transport vectors to the marginal and deep-lake core sites.

\section{Comparison of Vegetation and Lake Proxies}

Select results of the multiproxy approach at Lake Sidi Ali are shown in Figure 9. Inferences about past winter rainfall are based on the oxygen isotope composition of benthic ostracods, with enrichment in ${ }^{18} \mathrm{O}$ on orbital- to multi-centennial timescales associated with reduced influence of isotopically light, winter-season Atlantic moisture sources (Zielhofer et al., 2017a) within an overall highly evaporative closed-lake context (positive ${ }^{18} \mathrm{O}$ values). Changes in lake status (Unit 1 to Unit 5) are based on sedimentological proxies for terrestrial sediment supply (magnetic susceptibility, $\mathrm{K}$ concentrations) and lake sediment composition (calcium carbonate, $\mathrm{CaCO}_{3}$, and total organic carbon, TOC) (Figure 9). Lake-level inferences are further supported by sulfur and iron $(\mathrm{S} / \mathrm{Fe})$ ratios and ostracod abundances providing insights into hypolimnion conditions, as well as a preliminary diatom dataset and the derived planktonic/littoral (P/L) ratios (Zielhofer et al., 2017a). In general, low lake level phases (aerobic hypolimnion) correspond to higher precipitation of $\mathrm{CaCO}_{3}$, high ostracod abundances and enhanced magnetic susceptibility, while high lake level phases (anaerobic hypolimnion) are inferred from higher TOC-values, enhanced $\mathrm{S} / \mathrm{Fe}$ ratios and high $\mathrm{P} / \mathrm{L}$ ratios (Zielhofer et al., 2017a).

The compilation of proxies highlights how some vegetation and fire activity changes correspond to changes in lake status, including:

(i) The transition from steppe to wooded landscape in the Early Holocene (PAZ-1 to PAZ-2) and increasing CHAC accompanies indicators of rising/high lake levels from Unit 1 to Unit 3.

(ii) Maximum forest development (highest AP/NAP), the Holocene Cedrus maximum (PAZ-3c) and low CHAC and CHAR correspond with high lake level in Mid Holocene Unit $4 b$.

(iii) Shifts in forest composition (higher Cupressaceae, PAZ4) and increased fire regime (fluctuating high CHAR) accompany the transition from high to low lake level (Unit $4 \mathrm{~b}$ to $4 \mathrm{c}$ ) at the transition to the Late Holocene, along with increased abundance of Myriophyllum.

(iv) Forest cover decrease (low AP/NAP, PAZ-5) accompany indicators of catchment disturbance and soil erosion in Unit 5 along with highest Holocene CHAR peak.

Nevertheless, a broad contrast is apparent between prevailing high winter rainfall and high lake levels during the early Holocene and predominance of steppic and sclerophyll vegetation types in the pollen record. We interpret this contrast to reflect different predominant seasonal (winter/summer) sensitivity of the hydrological and vegetation proxies, and explore the detailed environmental and climatic implications of the record in the next section.

\section{Environmental Changes at Lake Sidi Ali PAZ-1 (12,000-10,340 cal yr BP)}

PAZ-1 reflects an open, non-forested landscape with Artemisia and Poaceae around Lake Sidi Ali during the PleistoceneHolocene transition and first centuries of the Holocene. AP percentages below $20 \%$ are consistent with frequencies observed in surface samples from non-forested areas of the Middle and High Atlas at present (Bell and Fletcher, 2016). Artemisiadominated vegetation does not have analogs in the Lake Sidi Ali area today, but is dominant in more arid environments with high continentality. In the Moulouya Basin (located to the east of the Middle Atlas), Artemisia herba-alba Asso is typical on poorly drained fine substrates-subject to some seasonal waterlogging - as part of an edaphic mosaic of steppe vegetation, alongside Stipa tenacissima L. (Poaceae) on rocky slopes and halophytic Chenopodiaceae where there is significant soil salinity (Emberger, 1939; Rhanem, 2009). Recurrent observations of Lygeum spartum in the pollen record, which develops on arid, saline soils, further point to high continentality and seasonal 


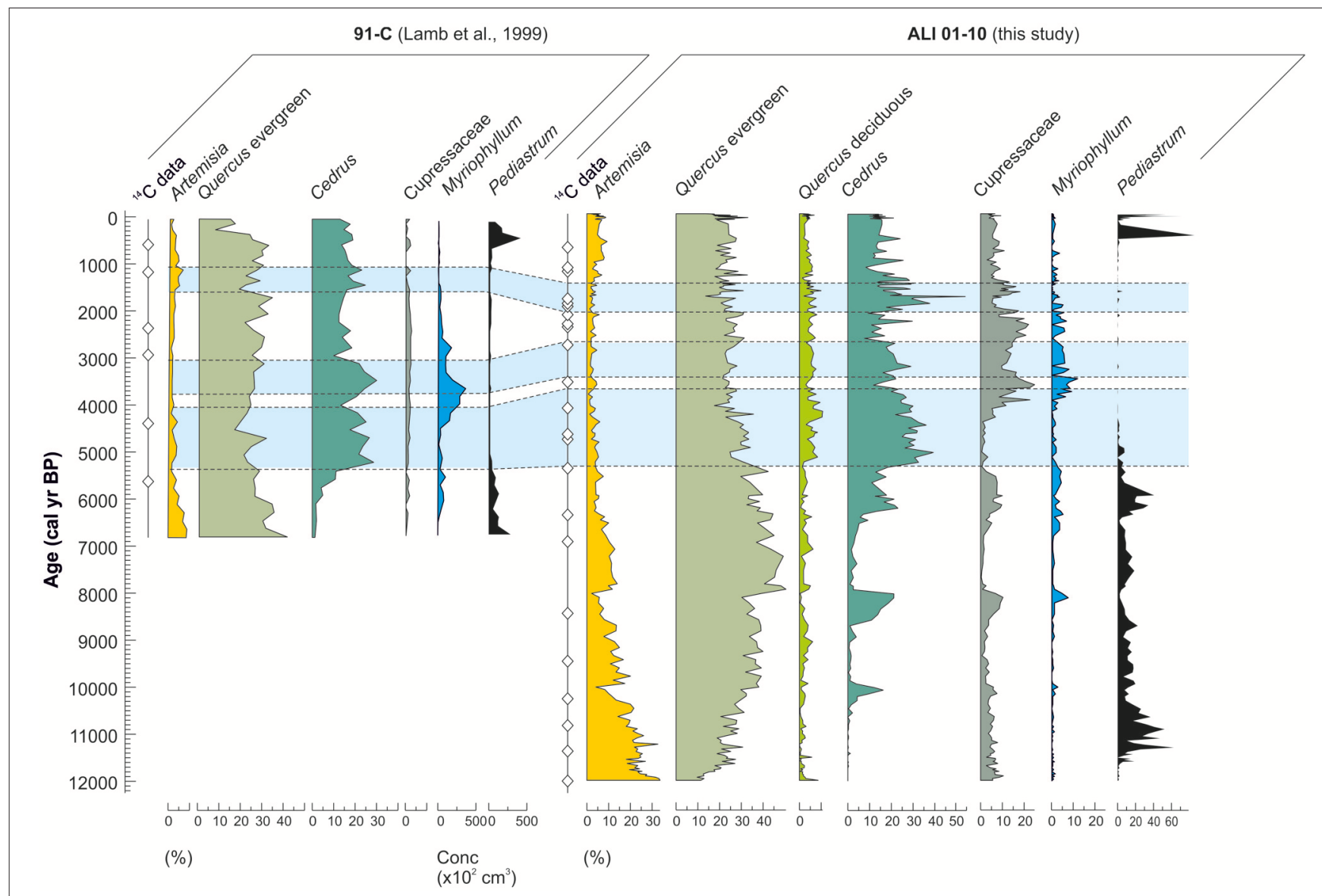

FIGURE 8 | Comparison of the pollen records from Lake Sidi Ali cores 91-C (Lamb et al., 1999) and ALI 01-10 (this study), showing select pollen taxa and radiocarbon chronological control.

aridity. Although non-arboreal vegetation was dominant, the moderate presence of shrubby sclerophylls (notably Pistacia) reflects pre-steppic woody formations developing under warm and dry conditions, probably at lower elevations. Low frequencies of evergreen Quercus may represent long-distance transport, although increasing values from 11,810 cal yr BP (PAZ-1b) suggest incipient afforestation processes in the Lake Sidi Ali sector.

A rapid increase in algal productivity is implied by the increasing, high abundances of colonial green algae (Botryococcus and Pediastrum) in PAZ-1b. Although very widely distributed, Botryococcus is commonly associated with seasonally cold climates in montane environments (Rull et al., 2008), and is favored by warm summer temperatures. Blooms of Pediastrum may similarly occur in response to several factors, but warm summer temperatures and possible nutrient enrichment associated with snowmelt at the onset of Holocene hydroclimatic conditions may be implicated here. Regional fire activity appears low despite prevailing arid conditions, pointing to fuel limitation as a primary constraint on wildfire at this time. Overall, the contrast between, on the one hand, inferred moderate to high lake levels and high winter precipitation (Figure 9) and, on the other, vegetation indications of semi-arid to arid bioclimate may be explained by very strong seasonal extremes, with concentration of precipitation as snowfall in the winter and warm dry summers.

\section{PAZ-2 (10,340-6,300 cal yr BP)}

PAZ-2 reflects the development of an open sclerophyll woodland with evergreen Quercus and, probably at lower elevations, Phillyrea. Pistacia continued to play a role in the regional vegetation, again probably at lower elevations and somewhat reduced in importance compared with PAZ-1. Afforestation in PAZ-2 represents an extension of processes commencing in PAZ$1 \mathrm{~b}$ and suggests an increase in moisture availability permitting arboreal development near the bioclimatic margins for tree growth. It is important to note that the evergreen Quercus pollen morphology (syn. Quercus ilex-type) in the Middle Atlas derives from Quercus rotundifolia. This sclerophyll tree occurs across an enormous altitudinal range in Morocco (300-2,800 m.a.s.l.) and is remarkable in its ecological plasticity (Barbero et al., 1992). It is tolerant of drought and high continentality, and is abundant across the meso- to montane-mediterranean vegetation levels in subhumid and semiarid bioclimates (Peguero-Pina et al., 2014). While the taxonomic status of the "rotundifolia" 


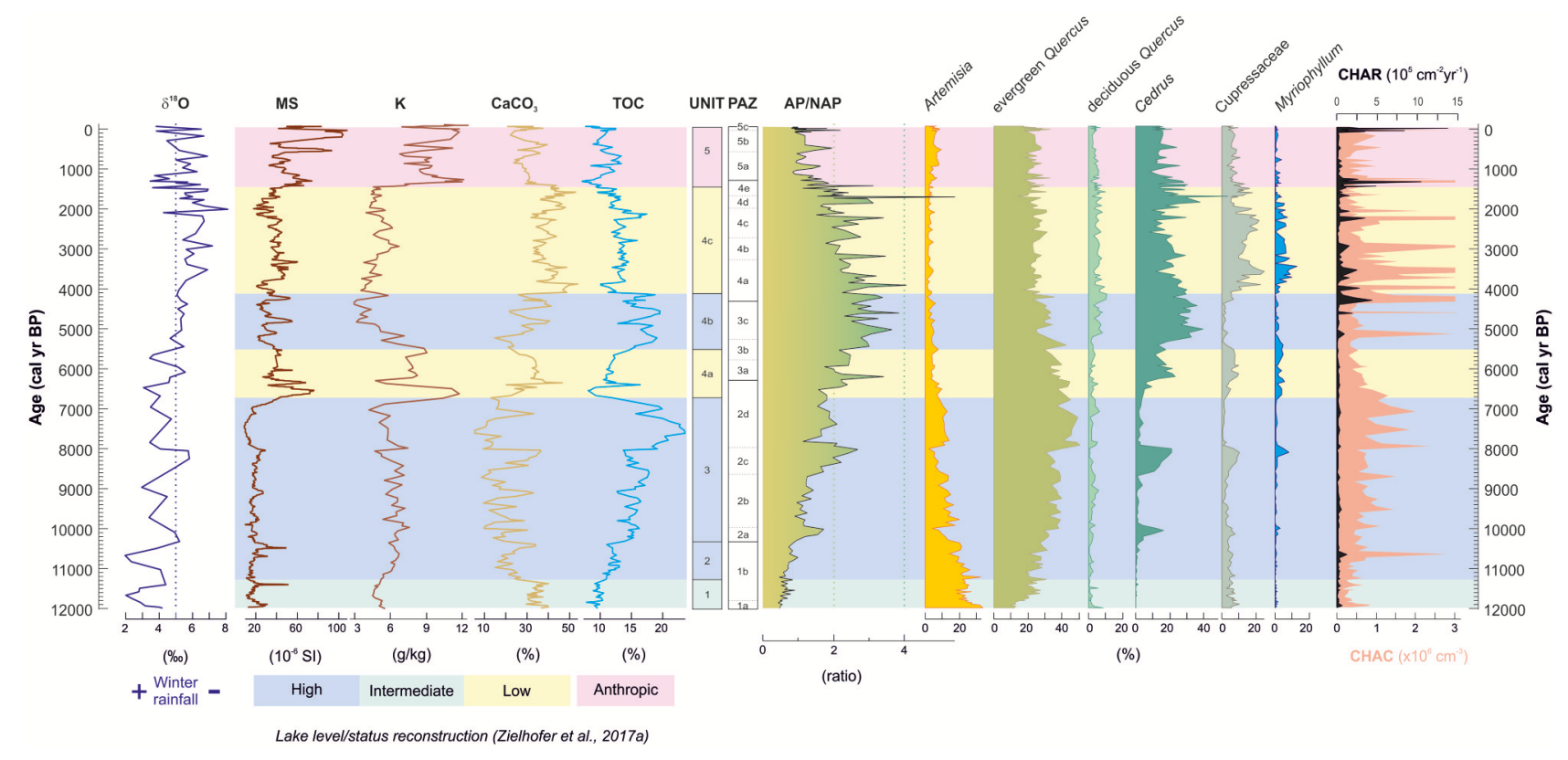

FIGURE 9 | Comparison of hydroclimate, catchment, vegetation and fire proxies at Lake Sidi Ali, showing (from left to right) stable oxygen isotope composition ( $\delta^{18} \mathrm{O}$ ) of benthic ostracods, core-scanning magnetic susceptibility, $\mathrm{K}$ concentration (benchtop XRF), $\mathrm{CaCO}_{3}$ and total organic carbon (TOC) content, and sediment unit classification (all data from Zielhofer et al., 2017a) alongside pollen assemblage zones (PAZ), forest cover proxy (AP/NAP ratio), select major pollen taxa, and fire proxies of microcharcoal concentration (CHAC) and microcharcoal accumulation rate (CHAR). Colored shading highlights changes in inferred lake level and human impact on the catchment (Zielhofer et al., 2017a).

morphotype is debated, it clearly represents a distinct ecotype with enhanced drought resistant functional traits compared with Q. ilex (Barbero et al., 1992). Evergreen Quercus pollen reaches maximum percentages and PARs in PAZ-2, indicating an important degree of drought stress under warm, summer-dry conditions in the Early Holocene. Parallel indications of summer warmth are provided by the abundant lake algae, Botryococcus, pointing to high lake productivity. Microcharcoal points to a moderate, stable background fire activity without exceptional fire episodes, gradually increasing in line with rising forest cover and lake level. These features suggest a continued role of fuel limitation at the regional scale.

Within PAZ-2, two well-defined episodes marked by increased Cedrus and Cupressaceae pollen (PAZ-2a and PAZ-2c) occured, commencing at 10,340 cal yr BP and 8,640 cal yr BP, respectively. Cedrus peaks exceed 15 and 20\%, respectively, during these episodes. In the study of soil surface samples from the Sidi Ali catchment (Bell and Fletcher, 2016), Cedrus percentages exceeding $7 \%$ were generally observed only in the immediate vicinity of Cedrus trees. The inferred low pollen dispersal of Cedrus, similar to that reported for the eastern Mediterranean species Cedrus libani A.Rich (Hajar et al., 2008), supports the interpretation of local presence of Cedrus stands in the Sidi Ali catchment during these episodes. Nevertheless, as the pollen transport pathways will be different for the lake basin and surface samples, notably with a greater contribution of a well-mixed atmospheric pollen rain into the lake basin, a longer-distance signal reflecting enhanced pollen production in select distant locales, or integrating across more numerous and productive patches in the wider landscape, cannot be ruled out. These episodes are also distinguished by isotope-inferred decreases in winter rainfall (Figure 9), increases in the submerged macrophyte Myriophyllum, and reductions in Pediastrum. Noting the general correlation between Myriophyllum and lowerlake-level phases (Figure 9), these changes suggest a combination of winter drying, lake level lowering and aquatic vegetation changes at the same time as summer cooling and reduced bioclimatic drought inferred from the expansion of montane conifers. Broadly, these indicators point to "cool summer, dry winter" episodes with diverse ecological impacts.

\section{PAZ-3 (6,300-4,320 cal yr BP)}

PAZ-3 represents a Mid Holocene transition in forest composition characterized by a decline in evergreen Quercus and the expansion of Cedrus. The floristic changes suggest a climatic transition toward generally cooler and more humid conditions favoring the development of montane conifer forest. A step-wise expansion of Cedrus is evident, initially accompanied by Cupressaceae at 6,300 cal yr BP (sub-zone PAZ-3a), and later accompanied by deciduous Quercus at 5,380 cal yr BP (PAZ-3c). The two phases of expansion leading to the dominance of Cedrus are separated by a minor regression during which warm-tolerant taxa Pistacia, Phillyrea, and Olea increased (PAZ-3b). The PAZ$3 a$ to PAZ-3b sequence, with contrasting expression of conifer and sclerophyll vegetation suggests the continuation of the dynamics prevailing in PAZ-2 and the superimposed impacts of cool-warm cycles onto the long-term transition from sclerophyll 
to conifer dominance. In this respect, Cedrus expansion in PAZ$3 \mathrm{a}$ in association with isotope-inferred winter rainfall decline suggests a further "cool summer, dry winter" interval centered around $6,100 \mathrm{cal} \mathrm{yr} \mathrm{BP.} \mathrm{In} \mathrm{contrast} \mathrm{to} \mathrm{the} \mathrm{prevailing} \mathrm{dynamics}$ evident in PAZ-2, where Cedrus appears to have undergone local extirpation during unfavorable episodes (PAZ-2b, PAZ-2d), long-term conditions from $6,300 \mathrm{cal}$ yr $\mathrm{BP}$ onwards permitted the development of a resilient local population of Cedrus at Lake Sidi Ali. Indeed, even the floristic characteristics during the minor regression of Cedrus in PAZ-3b point to slightly less arid bioclimate than that prevailing in PAZ-2b and PAZ-2d, reflected in the Holocene maximum representation of both Olea (a remote signal of thermophilous woody cover at low elevations) and Acer (probably a local component of summer-green vegetation on the lake margins).

Subsequently, maximum arboreal development for the Holocene was attained during a fairly stable interval with high values of Cedrus accompanied by increased deciduous Quercus between 5,280 and 4,320 cal yr BP (PAZ-3c). In concert with high lake levels (Unit 4b), these features suggest the Holocene interval of most humid bioclimate in the Middle Atlas. With regard to the isotope record, this humid interval does not appear to have been caused by especially high winter rainfall and is associated instead with intermediate isotopic values close to the long-term average (Figure 9). Rather, humidity signals at this time may result from the long-term (orbitally-driven) reduction in summer temperature and reduction in seasonal extremes (reduced summer drought, reduced concentration of precipitation in the winter season) leading to more favorable growing season conditions for moisture-sensitive taxa. The combined signals suggest development of moisture-demanding forest vegetation series with Cedrus in the montane belt around Lake Sidi Ali, and with deciduous Quercus at lower elevations (supra/upper mediterranean level). Alternatively, specimens of deciduous Quercus may have established alongside Cedrus in the Sidi Ali sector; however, the rather modest increase of this taxon in PAZ-3 in the context of recurring low values throughout the record may accord more strongly with a remote signal than a shift in local floristic composition. Low fire activity throughout PAZ-3 in the context of maximum arboreal development and floristic and limnological indications of humid bioclimate suggests a transition away from prevailing fuel-limitation during the Early Holocene toward a climate-limited fire dynamic after 6,300 cal yr BP.

\section{PAZ-4 (4,320-1,300 cal yr BP)}

PAZ-4 documents the continued dominance of montane conifer forest with Cedrus and, notably, Cupressaceae. PAZ-4 also reveals a modest, progressive opening of the forest cover from 4,320 cal yr BP onwards with increases in shrubby taxa and reduction of AP/NAP ratios. These changes accompanied lower lake level status and weakened influence of winter rainfall (Figure 9) and suggest a transition to generally drier conditions. A considerable decline in lake algae and increase in aquatic macrophytes (Myriophyllum), may also reflect either shallower lake levels and/or enhanced nutrient status (Lamb et al., 1999). At the same time, certain grazing resistant and waste ground taxa-notably,
Astragalus, Ulex and Coronilla types, reflecting spiny cushion form shrubs, along with Brassicaceae-may point to early signals of pastoral activity at this time. From 4,320 cal yr BP, a shift in fire activity is also evident, with frequent high amplitude fire episodes. This enhanced fire dynamic developed in the context of high forest cover and a shift to drier conditions, consistent with climate-limited fire dynamics from the Mid Holocene (PAZ3 ) onwards. The association of high fire frequency and early anthropogenic signals in PAZ-4 suggests that anthropogenic triggers for fire lighting may be implicated.

PAZ-4 subzones suggest a competitive dynamic between Cedrus and Cupressaceae in response to moisture increases (Cedrus) and decreases (Cupressaceae) under a generally cooler prevailing temperature regime than during the Early Holocene. The Late Holocene maxima in Cupressaceae (PAZ-4a, PAZ4c, PAZ-4e) probably represent local populations of Juniperus thurifera, the most prevalent Cupressaceae species around Lake Sidi Ali today. However, as Cupressaceae pollen is identifiable only to family level, the record may integrate several taxa with a range of thermic preferences, from the high mountain juniper, $J$. thurifera, and the fairly widespread J. oxycedrus, to warm climate taxa such as J. phoenicea and the western Mediterranean endemic, Tetraclinis articulata (Emberger, 1939). All taxa are, however, generally associated with semiarid conditions, supporting the inference of a drier affinity than Cedrus.

\section{PAZ-5 (1,300 cal yr BP to Present)}

PAZ-5 reflects an opening and degradation of the forest cover that affected Cedrus and Cupressacceae most strongly. The pollen spectra imply a prevalence of open ground areas with herbaceous vegetation, with Poaceae, Artemisia, Chenopodiaceae, Plantago types and Rumex. Following a major fire episode around 1,300 cal yr BP, fire activity appears generally low and stable, which may be a consequence of the opening of the vegetation cover and low flammable material due to grazing. The signals of deforestation are strongly supported by proxies for erosion and terrestrial input to the lake (Figure 9), and may have caused a pulse in nutrients promoting Pediastrum blooms. Within PAZ-5, three distinct phases are detected, reflecting a modest oscillation in arboreal cover (AP/NAP ratios, Table 1) with lowest arboreal cover and maximum Plantago between 1,300 cal yr BP and $580 \mathrm{cal}$ yr BP (PAZ-5a), a subsequent increase in Cedrus and evergreen Quercus after 580 cal yr BP (PAZ-5b), and a final reduction in the twentieth century (PAZ-5c). Although this pattern occurs within an anthropogenically-modified environment, it may reflect climatic influence on arboreal vegetation, particularly decreased drought stress during the Little Ice Age interval as documented in Middle Atlas Cedrus atlantica tree-ring widths (Esper et al., 2007).

\section{Local and Regional Patterns of Long-Term Ecological Change}

In order to differentiate local and regional signals, and examine vegetation development at two different elevations, it is informative to compare the Lake Sidi Ali and Tigalmamine records in detail. Key pollen taxa and AP/NAP ratios (Figure 10) highlight both commonalities and contrasts in vegetation history 
between these two sites located within $50 \mathrm{~km}$ distance. Key common features include:

(i) Peak abundance of Artemisia at the Pleistocene-Holocene transition and a parallel reduction during the Early Holocene, reflecting the gradual disappearance of regional steppic vegetation.

(ii) An Early Holocene maximum of evergreen Quercus at both sites, reflecting the maximum regional development of drought tolerant sclerophyll forest.

(iii) A Mid Holocene maximum for moisture-demanding taxa between ca. 5,000 and 4,000 cal yr BP with Cedrus at Lake Sidi Ali and deciduous Quercus at Tigalmamine.

(iv) An important role of Cedrus at both sites from 4,000 cal yr BP onwards.

Broadly, these parallels suggest a prevailing common influence of long-term regional climatic drivers. Essentially, they may be explained by a long-term cooling from an Early Holocene thermal maximum toward present, consistent with both summer insolation forcing (Berger and Loutre, 1991) and climate simulations (Renssen et al., 2009), accompanied by gradual reduction of seasonal temperature extremes and reduced temperature-driven summer drought stress associated with the precession cycle (Bosmans et al., 2015). At Lake Sidi Ali, a long-term reduction in the contribution of winter rainfall to the lake water is inferred (Figure 9, Zielhofer et al., 2017a), which might be assumed to counterbalance the positive effect of cooling on moisture availability for plant growth. However, in a high-insolation mountain setting with significant snowfall, winter precipitation may be subject to rapid melting and sublimation effects and hence of limited bioavailability during the growth season. While winter precipitation may ultimately help to recharge groundwater, only deep-rooting taxa (such as evergreen Quercus) will be able to take advantage of this water source to mitigate against summer drought, while shallow rooting taxa (e.g., Cedrus) depend on edaphic moisture sources and are more exposed to extended summer drought (Aussenac, 1984).

The interaction of these factors allows a model for regional environmental change related to long-term climatic drivers to be proposed. During the Early Holocene, a combination of cold, wet winters and hot, dry summers promoted the development of deep-rooting sclerophyll taxa and the persistence of steppic vegetation where aridity was too great. During the Mid Holocene, a "Goldilocks interval" where winter precipitation was moderately high, summer temperatures moderately warm and summer drought less intense promoted the maximum development of moisture demanding trees, similar to the phenomenon of the mesophytic forest maximum identified in SE Iberia mountain regions (Carrión, 2002; Carrión et al., 2003). During the Late Holocene, lower summer temperatures and reduced temperature-driven drought stress favored cool-tolerant and shallow-rooting forest taxa despite hydrological aridity resulting from reduced winter precipitation.

The specific timing and character of local vegetation responses to this long-term evolution will have been modulated by the

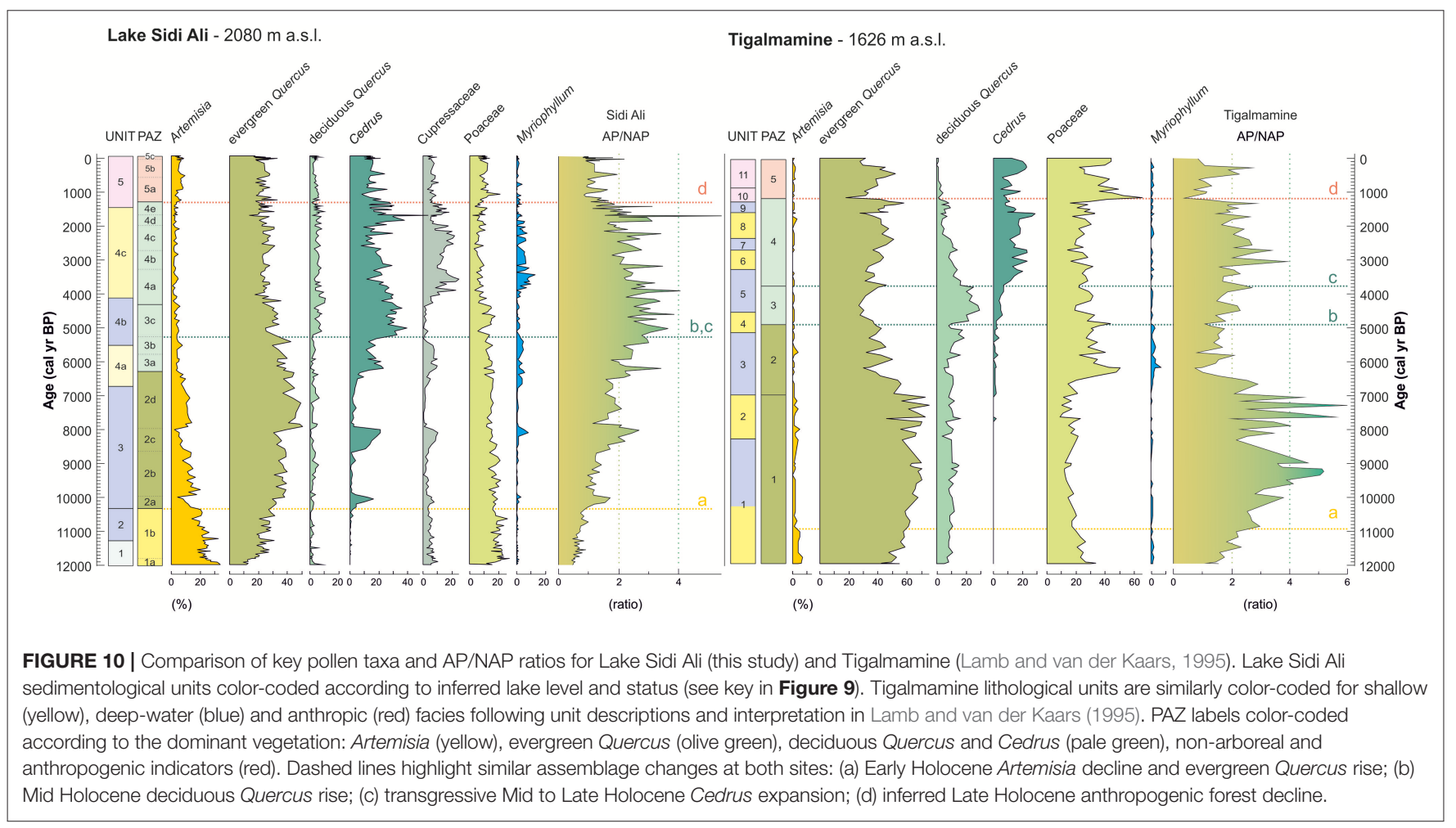


specific geographical and bioclimatic settings of the sites. Notable differences for Lake Sidi Ali and Tigalmamine (Figure 10) include:

(i) An important role of Cupressaceae at Lake Sidi Ali, particularly during the Late Holocene, while Cupressaceae is insignificant in Tigalmamine pollen record $(<1 \%)$.

(ii) Delayed expansion of Cedrus at Tigalmamine compared with Lake Sidi Ali.

(iii) Maximum forest development (AP/NAP ratios, Figure 10) was attained at Tigalmamine during the Early Holocene, but only during the Mid to Late Holocene at Lake Sidi Ali, with an opposed, corollary pattern for Poaceae.

These differences can be understood firstly with respect to the elevation of the sites. The elevation difference of $>450 \mathrm{~m}$ should account for a moderate prevailing temperature difference between the sites due to the normal lapse rate of $0.6^{\circ} \mathrm{C}$ per $100 \mathrm{~m}$. This difference is reflected nicely in the contrasting forest composition during the Mid Holocene under prevailing humid bioclimatic conditions (Cedrus at higher elevation vs. deciduous Quercus at lower elevation), and during the drier Late Holocene (Cedrus with Cupressaceae vs. evergreen Quercus with Cedrus). These patterns are coherent with characteristic vegetation differences along elevation gradients at present (Figure 3). Between the Mid and Late Holocene, the shift in vegetation composition can furthermore be understood to reflect an effective lowering of the regional vegetation levels in response to gradual cooling. The delayed expansion of Cedrus at the lower elevation site also points to local threshold responses to gradual cooling, with suitable conditions for Cedrus forest development reached earlier at higher elevations.

Secondly, Lake Sidi Ali is a significantly drier location (current semi-arid to subhumid bioclimate) than Tigalmamine (subhumid to humid bioclimate), primarily due to weaker influence of Atlantic-derived winter rainfall. As this difference is primarily linked to topographical controls arising from the NE-SW alignment of the Middle Atlas, it is likely to have remained fairly constant throughout the Holocene. In contrast, Mediterranean-sourced precipitation during the spring and autumn, and convective storms in summer, may play a more important role at Sidi Ali. A broadly consistent difference in aridity likely explains the important role of Artemisia steppe at the Pleistocene-Holocene transition and its greater persistence into the Early Holocene at Sidi Ali. Artemisia-rich steppe was dominant also at Tigalmamine during the Late Pleistocene (Lamb et al., 1989), but the expansion of sclerophyll woodland was more advanced by the onset of the Holocene. Similarly, greater aridity may also explain the weaker development of forest at Sidi Ali during the Early Holocene. Although evergreen Quercus was favored at both sites, a greater impact of high Early Holocene winter rainfall was probably effective at the more humid site. This may have been compounded by increased ecological challenges at the higher elevation site for colonization by seedlings.

The interplay of regional climatic changes and local conditions should have explanatory power for interpreting other existing and forthcoming Middle Atlas records. For example, at the nearby site of Ait Ichou (Tabel et al., 2016), located farther to the SW at similar elevation to Tigalmamine and in an intermediate bioclimatic setting between Lake Sidi Ali and Tigalmamine, common features with both records are observed. The site documents a synchronous Mid Holocene maximum with mesophytic deciduous Quercus and a Late Holocene expansion of Cedrus, reflecting similarities in forest composition changes with Tigalmamine related to gradual Holocene cooling. However, a Mid to Late Holocene maximum in forest development occurred that is similar to trends at Lake Sidi Ali, along with a strong persistence of Artemisia steppe into the Early Holocene; both features may be related to the drier setting that did not permit a strong response to enhanced Early Holocene winter rainfall.

In common with other Mediterranean climate regions, human impact and fire also appear to have played a role in the Holocene vegetation development, and within the study area many similarities are apparent in these factors. Broadly, at Lake Sidi Ali two phases of impact are recognized, with signals of matorralization (increase of shrubs) and enhanced fire activity apparent from around 4,300 cal yr BP, followed by a stronger horizon of impact with forest decline around 1,500-1,100 cal yr BP. These early responses have parallels at Ait Ichou, where development of Cistus scrub and increased burning is recorded around 4,500 cal yr BP. The coincidence of these changes and independent evidence for winter drying and lake level lowering at Lake Sidi Ali point to synergistic impacts of pastoral activities of the indigeneous Berber peoples of the Atlas and climate changes at the onset of the Late Holocene. Similar early signals were suggested for sites in the northern Middle Atlas (Afourgagh, Iffir) (Lamb et al., 1991), but predate the suggested 2,000 cal yr BP horizon of human impact reported for Ras el Ma, Tifounassine and sites in the Rif (Cheddadi et al., 2015). Important similarities with fire activity in SE Iberia (Gil-Romera et al., 2010) are noted, notably modest fire activity during the Early Holocene in a fuel-load limited system, low fire activity during a humid Mid Holocene associated with the installation of Cedrus at Lake Sidi Ali and a mesophytic tree maximum in SE Iberia, and dynamic fire activity during the Late Holocene in the context of drying and increased human activity.

The second phase, marked by strong forest cover reduction and Cedrus decline in the first millennium $\mathrm{AD}$, is evident at all sites in the southern Middle Atlas, including Lake Sidi Ali, Tigalmamine (Lamb et al., 1995), Ait Ichou (Tabel et al., 2016), Taguelmam n'Harcha (Lamb et al., 1991), and Col du Zad (Reille, 1976). The timing at Sidi Ali (PAZ-5 boundary, 1,300 cal yr BP, or $650 \mathrm{AD}$ ) suggests a possible association with more intensive use of forest resources in the Middle Atlas following the Early Muslim conquest of Northwest Africa in the mid seventh century AD (Abun-Nasr, 1987). As such, the forest decline in the southern Middle Atlas may be part of a wider phase of significant first millennium $\mathrm{AD}$ anthropogenic impact in mountain environments extending to the High Atlas (McGregor et al., 2009; Fletcher and Hughes, 2017). The two-phase forest decline at Sidi Ali represents an valuable example of the wider phenomenon of montane conifer forest decline in the face of intensification of human pressure on Mediterranean mountain environments and changes in fire activity, which includes Abies alba in Italy (Tinner et al., 2013), and Pinus nigra and P. sylvestris 


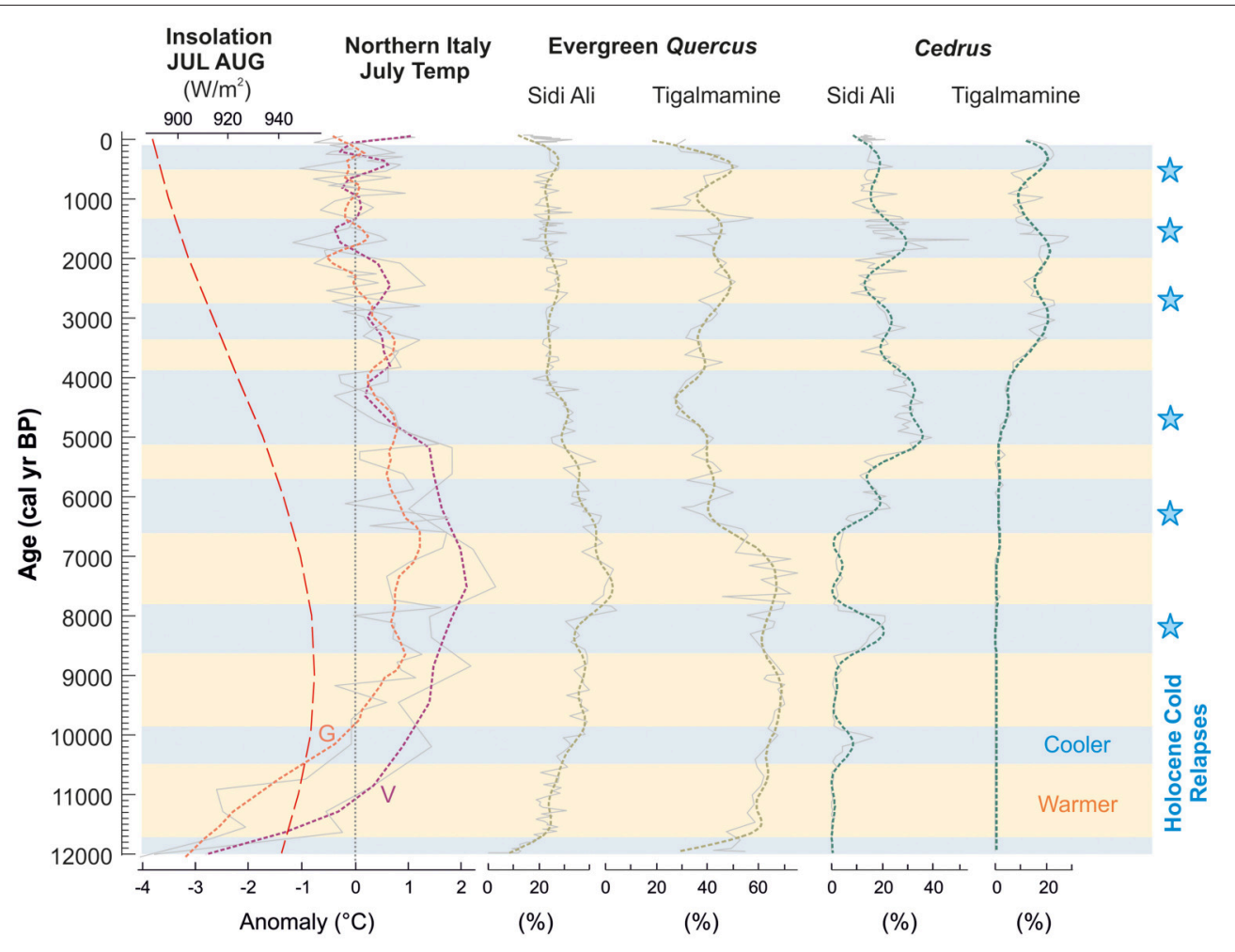

FIGURE 11 | Inferred summer temperature variability in the Middle Atlas, Morocco, showing: orbital insolation parameter for combined July and August insolation at $30^{\circ} \mathrm{N}$ (Berger and Loutre, 1991); chironomid-based summer temperature reconstructions from Gemini (G) and Verdarolo (V) in northern Italy (Samartin et al., 2017); pollen curves for warm-tolerant (evergreen Quercus) and cool-tolerant (Cedrus) trees at Lakes Lake Sidi Ali (this study) and Tigalmamine (Lamb and van der Kaars, 1995). Dashed lines through the pollen curves show results of lowpass filter (1,000 year) removing centennial variability. Stars indicate global Holocene "cold relapses" (Wanner et al., 2011).

in Iberia (Rubiales et al., 2012; Morales-Molino et al., 2017). The details of the temporal, cultural and climatic context appear regionally-specific, and a synthetic treatment of the shared and unique features of the historical trajectories of these vulnerable organisms could be a valuable future research avenue.

\section{Impacts of Long-Term and Millennial-Scale Summer Temperature Changes}

The important role of two climate-sensitive species at Lake Sidi Ali and Tigalmamine supports the investigation of common trends and patterns of millennial-scale variability. As discussed above, the contrasting rooting depths of Cedrus atlantica and Quercus rotundifolia relate to different strategies for maintaining photosynthetic activity during summer drought. Cedrus atlantica develops an extensive shallow root system and tolerates drought through gradual reduction of stomatal conductance to reduce transpiration, maintaining photosynthetic activity under considerable hydric stress. However, lack of transpiration blockage can lead to difficulties under prolonged, severe drought (Aussenac, 1984). In contrast, Quercus rotundifolia develops deep rooting structures to access groundwater reserves and maintain high rates of transpiration in combination with stomatal closure under extreme stress (David et al., 2004; Cubera and
Moreno, 2007; Vaz et al., 2010). These different strategies leave Cedrus more vulnerable to extended temperature-driven summer drought and low soil moisture. This phenomenon is implicated in current dieback of Cedrus in NW Africa (Linares et al., 2011; Rhanem, 2011) and encroachment of Quercus rotundifolia into cedar forest areas (Figure 4). Field observations highlight the current decline at the lower limits of the species' elevation range and a healthy state toward the upper limits, further supporting temperature-driven abiotic stress as a key driver of ongoing dieback (Rhanem, 2011).

Figure 11 highlights opposed trends on long-term and millennial timescales between warm-tolerant evergreen Quercus and cool-preferring Cedrus. We find that the long-term trend is in good agreement with orbital forcing during summer (July, August) (Berger and Loutre, 1991) and with the chironomidbased temperature reconstructions of Samartin et al. (2017) for Mediterranean northern Italy. Millennial phases of warmer and cooler bioclimate are also inferred and again these show good coherence with signals in Mediterranean northern Italy. Despite the remote location of the Verdarolo and Gemini reconstructions, similarities with NW Africa would be anticipated from significant correlations in July temperatures between the regions ( $r=0.3-0.5$, Samartin et al., 2017). The millennial patterns of warmer and cooler temperatures also show 
coherent signals with respect to well-known Holocene cooling intervals, such as multi-centennial summer cooling around the short-lived $8.2 \mathrm{ka}$ event (Rohling and Pälike, 2005), and the socalled "cold relapses" around 8,200, 6,300, 4,700, 2,700, 1,550, and $550 \mathrm{cal} \mathrm{yr} \mathrm{BP}$ identified in global records by Wanner et al. (2011). It is noteworthy that the last of these relapses, associated with the Northern Hemisphere Little Ice Age, is evident in Cedrus expansion at both sites, weakly at Lake Sidi Ali and more strongly at Tigalmamine, even though this climatic shift occurred after the main horizon of anthropogenic impact on the landscape. In contrast to lowland Mediterranean areas, where precipitation changes are implicated as the main driver of millennial-scale vegetation changes, including forest declines (Fletcher et al., 2013) and matorral-steppe fluctuations (Jaouadi et al., 2016), we suggest that the temperature component of millennial-scale climate variability may have been a key driver in the Middle Atlas, impacting directly on growing season bioclimate and modulating the intensity of summer drought.

The match between the records of evergreen Quercus at Lake Sidi Ali and Tigalmamine and the Italian records supports an Early Holocene summer thermal maximum between 9,000 and

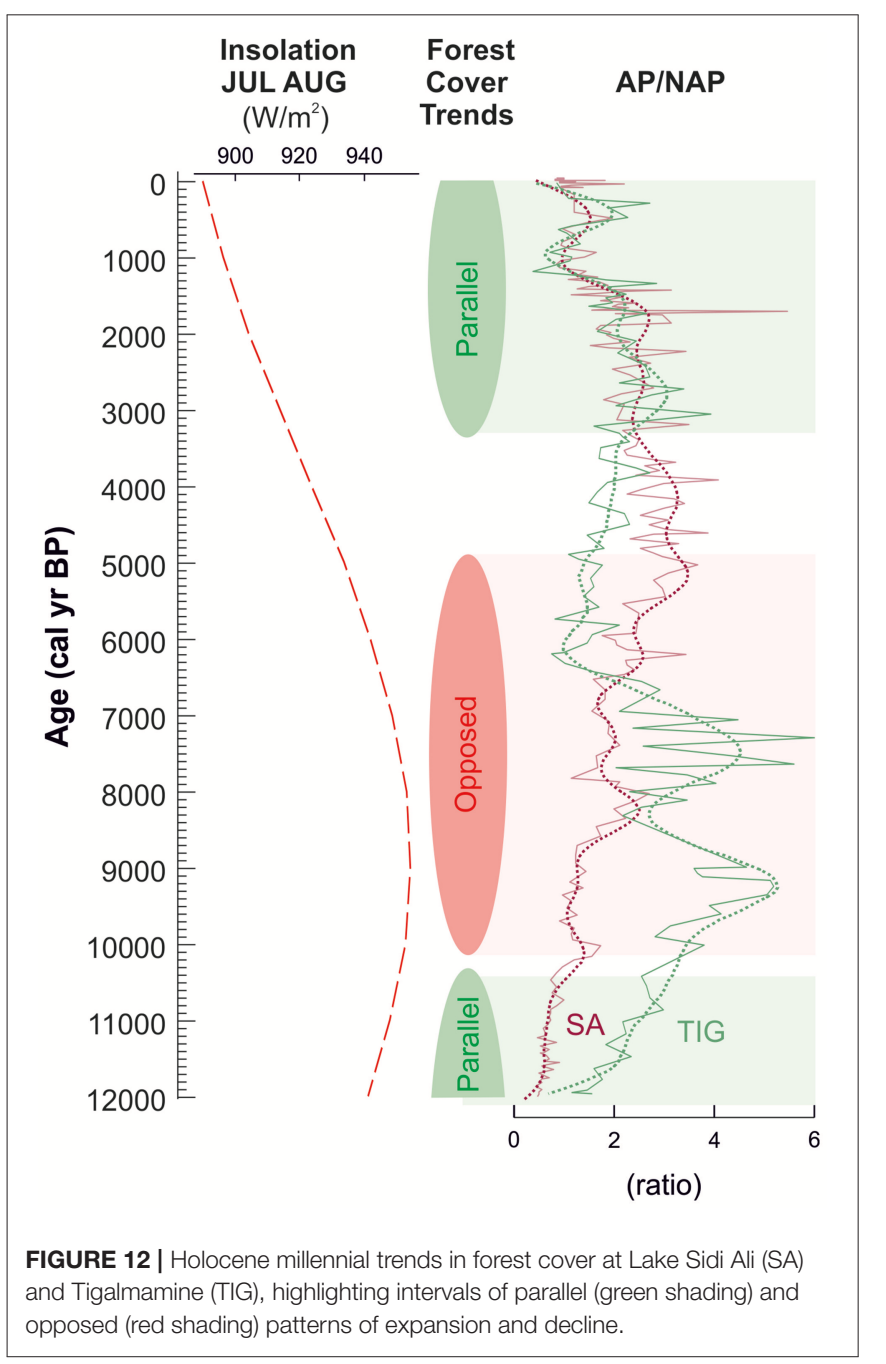

7,000 cal yr BP in the Middle Atlas, interrupted by a multicentennial interval of summer cooling around 8,000 cal yr BP. More widely, an important role of Early Holocene high summer temperatures is implicated in strong development of evergreen Quercus in the Alboran Sea basin regions of S Iberia and N Morocco (Fletcher and Goñi, 2008; Combourieu Nebout et al., 2009) and southern Portugal (Fletcher et al., 2007). High temperatures during the Early Holocene are also implicated in the maximum depletion in speleothem ${ }^{13} \mathrm{C}$ by $9,500 \mathrm{cal} \mathrm{yr} \mathrm{BP}$ at La Mine Cave in Tunisia associated with enhanced soil microbial activity above the cave (Genty et al., 2006). The summer thermal maximum inferred from the Middle Atlas pollen records is coherent with insolation forcing and model predictions (Renssen et al., 2009). In contrast, it does not support the results of large-scale pollen-based climate reconstructions (Davis et al., 2003; Mauri et al., 2015) which produce cool Early Holocene temperatures for the SW European/W Mediterranean sector. The challenge for pollen-based reconstructions in the Mediterranean climate zone is the interaction of temperature and precipitation changes in determining bioclimatic moisture availability for vegetation development, and hence the truly independent reconstruction of either temperature or precipitation. In this case, the multiproxy approach at Lake Sidi Ali indicates high lake levels and strong influence of winter precipitation during the Early Holocene (particularly evident in anaerobic hypolimnion conditions favoring organic preservation and light oxygen isotope signatures; Figure 9). As such, an alternative scenario that the vegetation changes essentially reflect a shift from low to high precipitation changes can be rejected, with a caveat relating to possible enhancement of summer precipitation over the Holocene in line with precession forcing (Bosmans et al., 2015). More widely, another challenge for continental-scale reconstructions will be the merging of signals from Quercus rotundifolia (extensive across NW Africa and S Iberia) and Quercus ilex (in NW, central and E Mediterranean sectors), given the very different tolerances for high continentality of these species.

\section{Implications for Future Change}

The pollen records of Lake Sidi Ali and Tigalmamine reveal the significant exposure of forest vegetation to pervasive millennial climate changes in the Middle Atlas. This finding contrasts with other areas of the western Mediterranean where vegetation resilience in the face of rapid climate changes has been identified, such as the continental interior of eastern Iberia (Aranbarri et al., 2014). The picture reinforces the view of high sensitivity of mountain regions to climatic changes, as predicted for the Twenty-first century (Nogués-Bravo et al., 2007). Importantly, fluctuations in the relative abundance of evergreen Quercus and Cedrus (Figure 12) persisted even in an anthropogenically altered landscape. Indeed, from a Holocene perspective, the current decline of Cedrus atlantica may be understood partly as a response to a quasi-periodic Holocene fluctuation in climate and less favorable conditions since the end of the Little Age Ice. However, the pollen records also indicate that total forest cover is at the lowest level since the onset of the Holocene, increasing the vulnerability of Cedrus to regional extirpation due to reduced 
population size and range fragmentation. Moreover, projected increases in summer heat stress in the context of anthropogenic global change will exacerbate the natural trend, pushing the species toward extinction from many areas of its current range (Cheddadi et al., 2009).

The Holocene perspective on total forest cover at Lake Sidi Ali and Tigalmamine (Figure 12) highlights a second implication of future warming. Similar trends of forest increase following the Pleistocene-Holocene transition and Late Holocene decline during the last 3,000 years are observed at both sites, consistent with broadly parallel trajectories of climatic and anthropogenic forcing (Figure 12, green shaded intervals). However, the patterns diverge during the Early Holocene, especially near the Early Holocene summer thermal maximum, when forest cover changes in response to millennial fluctuations were opposed in direction (Figure 12, red shading). This is most clearly evident for two inferred warm phases centered around 9,500 and 7,500 cal yr BP (Figure 12). We suggest that under a prevailing high summer temperature regime, forest vegetation at the site receiving higher winter rainfall (Tigalmamine) could respond positively to millennial intervals of summer warming, while the same warming intervals lead to forest declines at the drier site (Lake Sidi Ali). Our findings are similar to long-term observations in the Canadian Cordillera (Schwörer et al., 2017), where Holocene forest dynamics were modulated by millennial temperature changes, but the development of closed forest was limited by topographical and geomorphological controls on moisture availability. Our findings suggest that in a warmer future, forest response to climate will be spatially complex. Higher temperatures will exacerbate differences in moisture availability associated with topography and elevation, leading to divergent patterns of productivity, biomass and carbon sequestration within the region.

\section{CONCLUSIONS}

The high-resolution and robustly-dated pollen record from Lake Sidi Ali documents the Holocene vegetation history at a high elevation site in the southern Middle Atlas and provides multiple insights into the environmental drivers of ecological change. Five main vegetation phases are identified, of which the first four appear climatically-driven, namely: (i) Artemisia steppe between 12,000 and 10,340 cal yr BP under a semiarid, continental regime, (ii) open sclerophyll woodland with evergreen Quercus between 10,340 and 6,300 cal yr B under a warm, subhumid regime with marked summer drought, (iii) transition to Cedrus forest between 6,300 and 4,320 ca yr BP under a cool, humid to subhumid regime with reduced summer drought, and (iv) gradual decline of cold-tolerant montane conifer forests with Cedrus and Cupressaceae between 4,320 and $1,300 \mathrm{cal}$ yr BP under a cool, subhumid to semiarid regime. The succession of changes points to a primary influence of long-term climatic drivers including gradual reduction in seasonal extremes of winter precipitation and summer drought, consistent with lake level and rainfall proxies from the same core. Associated changes in fire activity suggest a shift from fuel-load limitation to climate-limitation from the Early to Mid Holocene, and reveal a significant increase in fire activity in the Late Holocene. Anthropogenic impact may be implicated in processes of matorralization and enhanced fire activity from $4,320 \mathrm{cal}$ yr BP, but the timing coincides with lake level lowering and reduced winter rain during the Late Holocene and synergistic climate-human impacts may be implicated. The fifth phase (v) reflects opening and degradation of the forest cover from 1,300 cal yr BP, and probably marks a horizon of more intense human impact, evident across the southern Middle Atlas (Reille, 1976; Lamb et al., 1991; Tabel et al., 2016).

The detailed comparison of the pollen records from Lake Sidi Ali and Tigalmamine (Lamb and van der Kaars, 1995) on their respective age models provides valuable insights into forest cover and composition at two different altitudes within the same southern Middle Atlas region. The main phases of vegetation change are replicated, but elevation and precipitation differences contribute to site specific patterns. Notably, the Mid Holocene interval of maximum bioclimatic humidity (dated from 5,280 to $4,320 \mathrm{cal} \mathrm{yr} \mathrm{BP}$ at Lake Sidi Ali) is reflected in a Cedrus maximum at higher elevation and a deciduous Quercus (Q. canariensis) maximum at lower elevation. Throughout the Holocene, similar dynamics are observed at the sites in terms of fluctuating, opposed evergreen Quercus and Cedrus abundances. These dynamics can be understood in terms of the different drought tolerance mechanisms for these taxa, and may be predominantly controlled by summer temperature influence on moisture availability. The inferred summer temperature changes suggest a Holocene summer temperature maximum between 9,000 and 7,000 cal yr BP (Samartin et al., 2017) and pervasive millennial-scale climate variability. Millennial cooling episodes favoring expansion of Cedrus were centered around 10,200, $8,200,6,100,4,500,3,000$, and $1,700 \mathrm{cal} \mathrm{yr} \mathrm{BP}$, as well as during the Little Ice Age (400 cal yr BP). These climate-driven fluctuations persist through the Late Holocene, despite opening of the forest cover and intensification of human impact.

The results demonstrate the sensitive response of Middle Atlas forests to rapid climate changes, and underscore the important influence of temperature regime on vegetation dynamics in this mountain region. The negative implications of temperature increase for Cedrus are reinforced (Cheddadi et al., 2009) and spatial complexity of future changes in forest cover and productivity appear likely in light of divergent trends of forest cover during the Early to Mid Holocene thermal maximum.

\section{AUTHOR CONTRIBUTIONS}

JC undertook pollen and charcoal analyses and wrote the first draft of the manuscript. WF designed the study and revised the final version of the manuscript. SJ undertook pollen and charcoal analyses. PH and MR provided scientific input to the project conception and interpretation of the data. CZ was responsible for the fieldwork, provided multiproxy data and scientific input to the data interpretation. All authors contributed to the preparation and revision of the manuscript. 


\section{ACKNOWLEDGMENTS}

This study was funded by the Natural Environment Research Council UK (New Investigator Award NE/K000608/1), the German Research Foundation (grant no. DFG ZI 721/9-1), and a School of Environment, Education and Development $\mathrm{PhD}$ scholarship to JC. We gratefully acknowledge fieldwork support from the Institut National des Sciences de l'Archéologie

\section{REFERENCES}

Abdeddaim-Boughanmi, K., and Kaid-Harche, M. (2009). Structure, ultrastructure of the anther, pollen microsporogenesis and morphology of pollen grains of two populations of Lygeum spartum L. Algeria. A. J. Agric. Biol. Sci. 4, 201-205. doi: 10.3844/ajabssp.2009.201.205

Abun-Nasr, J. M. (ed.) (1987). A History of the Maghrib in the Islamic Period. Cambridge: Cambridge University Press.

Achhal, A., Akabli, O., Barbero, M., Benabid, A., M'hirit, A., Peyre, C., et al. (1980). A propos de la valeur bioclimatique et dynamique de quelques essences forestières au Maroc. Ecol. Mediterr. 5, 211-249.

Aranbarri, J., González-Sampériz, P., Valero-Garcés, B., Moreno, A., Gil-Romera, G., Sevilla-Callejo, M., et al. (2014). Rapid climatic changes and resilient vegetation during the Lateglacial and Holocene in a continental region of south-western Europe. Glob. Planet. Change 114, 50-65. doi: 10.1016/j.gloplacha.2014. 01.003

Arboleya, M. L., Teixell, A., Charroud, M., and Julivert, M. (2004). A structural transect through the High and Middle Atlas of Morocco. J. Afr. Earth Sci. 39, 319-327. doi: 10.1016/j.jafrearsci.2004.07.036

Aussenac, G. (1984). Le Cèdre, essai d'interprétation bioclimatique et écophysiologique. Bull. Soc. Bot. France Actual. Bot. 131, 385-398. doi: 10.1080/01811789.1984.10826679

Barbero, M., Loisel, R., and Quézel, P. (1992). Biogeography, ecology and history of mediterranean Quercus ilex ecosystems. Vegetatio 99, 19-34. doi: 10.1007/BF00118207

Barker, P. A., Roberts, N., Lamb, H. F., van der Kaars, S., and Benkaddour, A. (1994). Interpretation of Holocene lake-level change from diatom assemblages in Lake Sidi Ali, Middle Atlas, Morocco. J. Paleolimnol. 12, 223-234. doi: 10.1007/BF00678022

Bell, B. A., and Fletcher, W. J. (2016). Modern surface pollen assemblages from the Middle and High Atlas, Morocco: insights into pollen representation and transport. Grana 55, 286-301. doi: 10.1080/00173134.2015.1108996

Benabid, A. (1982). Bref aperçu sur la zonation altitudinale de la végétation climacique du Maroc. Ecol. Mediterr. 8, 301-315.

Bennett, K. D. (1996). Determination of the number of zones in a biostratigraphical sequence. New Phytol. 132, 155-170. doi: 10.1111/j.1469-8137.1996.tb04521.x

Berger, A., and Loutre, M. F. (1991). Insolation values for the climate of the last 10 million years. Q. Sci. Rev. 10, 297-317. doi: 10.1016/0277-3791(91)90033-Q

Beug, H.-J. (2004). Leitfaden der Pollenbestimmung für Mitteleuropa und Angrenzende Gebiete. Munich: Verlag Dr. Friedrich Pfeil.

Birks, H. H., and Birks, H. J. B. (2006). Multi-proxy studies in palaeolimnology. Veg. Hist. Archaeobot. 15, 235-251. doi: 10.1007/s00334-006-0066-6

Blondel, J. (2006). The 'design'of Mediterranean landscapes: a millennial story of humans and ecological systems during the historic period. Hum. Ecol. 34, 713-729. doi: 10.1007/s10745-006-9030-4

Born, K., Fink, A. H., and Knippertz, P. (2010). "Meteorological processes influencing the weather and climate of Morocco," in Impacts of Global Change on the Hydrological Cycle in West and Northwest Africa, eds P. Speth, M. Christoph, and B. Diekkrüger (Berlin; Heidelberg: Springer), 150-163.

Born, K., Fink, A. H., and Paeth, H. (2008). Dry and wet periods in the northwestern Maghreb for present day and future climate conditions. Meteorolog. Z. 17, 533-551. doi: 10.1127/0941-2948/2008/0313

Bosmans, J. H. C., Drijfhout, S. S., Tuenter, E., Hilgen, F. J., Lourens, L. J., and Rohling, E. J. (2015). Precession and obliquity forcing of et du Patrimoine (INSAP, Rabat), Caidad d'Azrou and the Centre National d'Hydrobiologie et de Pisciculture. We thank John Moore and Jonathan Yarwood of the Physical Geography Laboratories (University of Manchester) for technical support. We are grateful to Steffen Mischke for helpful comments on the draft manuscript, and to Henry Lamb and Cesar Morales Del Molino whose constructive reviews helped improve the final manuscript. the freshwater budget over the Mediterranean. Q. Sci. Rev. 123, 16-30. doi: 10.1016/j.quascirev.2015.06.008

Bronk Ramsey, C. (2008). Deposition models for chronological records. Q. Sci. Rev. 27, 42-60. doi: 10.1016/j.quascirev.2007.01.019

Campbell, J. F. E., Fletcher, W. J., Hughes, P. D., and Shuttleworth, E. L. (2016). A comparison of pollen extraction methods confirms dense-media separation as a reliable method of pollen preparation. J. Q. Sci. 31, 631-640. doi: $10.1002 /$ jqs. 2886

Carrión, J. S. (2002). Patterns and processes of Late Quaternary environmental change in a montane region of southwestern Europe. Q. Sci. Rev. 21, 2047-2066. doi: 10.1016/S0277-3791(02)00010-0

Carrión, J. S., Sánchez-Gómez, P., Mota, J. F., Yll, R., and Chaín, C. (2003). Holocene vegetation dynamics, fire and grazing in the Sierra de Gádor, southern Spain. Holocene 13, 839-849. doi: 10.1191/0959683603hl662rp

Cheddadi, R., Fady, B., François, L., Hajar, L., Suc, J. P., Huang, K., et al. (2009). Putative glacial refugia of Cedrus atlantica deduced from Quaternary pollen records and modern genetic diversity. J. Biogeogr. 36, 1361-1371. doi: 10.1111/j.1365-2699.2008.02063.x

Cheddadi, R., Lamb, H. F., Guiot, J., and van der Kaars, S. (1998). Holocene climatic change in Morocco: a quantitative reconstruction from pollen data. Clim. Dyn. 14, 883-890. doi: 10.1007/s003820050262

Cheddadi, R., Nourelbait, M., Bouaissa, O., Tabel, J., Rhoujjati, A., López-Sáez, J. A., et al. (2015). A history of human impact on Moroccan mountain landscapes. Afr. Archaeol. Rev. 32, 233-248. doi: 10.1007/s10437-015-9186-7

Combourieu Nebout, N., Peyron, O., Dormoy, I., Desprat, S., Beaudouin, C., Kotthoff, U., et al. (2009). Rapid climatic variability in the west Mediterranean during the last 25000 years from high resolution pollen data. Clim. Past 5, 503-521. doi: 10.5194/cp-5-503-2009

Cubera, E., and Moreno, G. (2007). Effect of single Quercus ilex trees upon spatial and seasonal changes in soil water content in dehesas of central western Spain. Ann. For. Sci. 64, 355-364. doi: 10.1051/forest:2007012

David, T. S., Ferreira, M. I., Cohen, S., Pereira, J. S., and David, J. S. (2004) Constraints on transpiration from an evergreen oak tree in southern Portugal. Agric. Forest Meteorol. 122, 193-205. doi: 10.1016/j.agrformet.2003.09.014

Davis, B. A., Brewer, S., Stevenson, A. C., and Guiot, J. (2003). The temperature of Europe during the Holocene reconstructed from pollen data. Q. Sci. Rev. 22, 1701-1716. doi: 10.1016/S0277-3791(03)00173-2

Dawson, T. P., Jackson, S. T., House, J. I., Prentice, I. C., and Mace, G. M. (2011). Beyond predictions: biodiversity conservation in a changing climate. Science 332, 53-58. doi: 10.1126/science. 1200303

De Waele, J., and Melis, M. T. (2009). Geomorphology and geomorphological heritage of the Ifrane-Azrou region (Middle Atlas, Morocco). Environ. Geol. 58, 587-599. doi: 10.1007/s00254-008-1533-4

Diffenbaugh, N. S., and Scherer, M. (2011). Observational and model evidence of global emergence of permanent, unprecedented heat in the 20th and 21st centuries. Clim. Change 107, 615-624. doi: 10.1007/s10584-011$0112-y$

Emberger, L. (1939). Aperçu Général sur la Végétation du Maroc: Commentaire de la Carte Phytogéographique du Maroc 1: 1500000. Berne: H. Huber.

Esper, J., Frank, D., Büntgen, U., Verstege, A., Luterbacher, J., and Xoplaki, E. (2007). Long-term drought severity variations in Morocco. Geophys. Res. Lett. 34:L17702. doi: 10.1029/2007GL030844

Finsinger, W., and Tinner, W. (2005). Minimum count sums for charcoal concentration estimates in pollen slides: accuracy and potential errors. Holocene 15, 293-297. doi: 10.1191/0959683605hl808rr 
Fletcher, W. J., Boski, T., and Moura, D. (2007). Palynological evidence for environmental and climatic change in the lower Guadiana valley, Portugal, during the last 13000 years. Holocene 17, 481-494. doi: $10.1177 / 0959683607077027$

Fletcher, W. J., Debret, M., and Goñi, M. F. S. (2013). Mid-Holocene emergence of a low-frequency millennial oscillation in western Mediterranean climate: implications for past dynamics of the North Atlantic atmospheric westerlies. Holocene 23, 153-166. doi: 10.1177/0959683612460783

Fletcher, W. J., and Goñi, M. F. S. (2008). Orbital-and sub-orbital-scale climate impacts on vegetation of the western Mediterranean basin over the last 48,000 yr. Q. Res. 70, 451-464. doi: 10.1016/j.yqres.2008. 07.002

Fletcher, W. J., and Hughes, P. D. (2017). Anthropogenic trigger for Late Holocene soil erosion in the Jebel Toubkal, High Atlas, Morocco. Catena 149, 713-726. doi: 10.1016/j.catena.2016.03.025

Fletcher, W. J., Zielhofer, C., Mischke, S., Bryant, C., Xu, X., and Fink, D. (2017). AMS radiocarbon dating of pollen concentrates in a karstic lake system. $Q$. Geochronol. 39, 112-123. doi: 10.1016/j.quageo.2017.02.006

Fyfe, R. M., de Beaulieu, J. L., Binney, H., Bradshaw, R. H., Brewer, S., Le Flao, A., et al. (2009). The European Pollen Database: past efforts and current activities. Veg. Hist. Archaeobot. 18, 417-424. doi: 10.1007/s00334-009-0215-9

Genty, D., Blamart, D., Ghaleb, B., Plagnes, V., Causse, C., Bakalowicz, M., et al. (2006). Timing and dynamics of the last deglaciation from European and North African $\delta 13 \mathrm{C}$ stalagmite profiles-comparison with Chinese and South Hemisphere stalagmites. Q. Sci. Rev. 25, 2118-2142. doi: 10.1016/j.quascirev.2006.01.030

Giesecke, T., and Fontana, S. L. (2008). Revisiting pollen accumulation rates from Swedish lake sediments. Holocene 18, 293-305. doi: 10.1177/0959683607086767

Gil-Romera, G., Carrión, J. S., Pausas, J. G., Sevilla-Callejo, M., Lamb, H. F., Fernández, S., et al. (2010). Holocene fire activity and vegetation response in South-Eastern Iberia. Q. Sci. Rev. 29, 1082-1092. doi: 10.1016/j.quascirev.2010.01.006

Giner, M. M., García, J. S. C., and Camacho, C. N. (2002). Seasonal fluctuations of the airborne pollen spectrum in Murcia (SE Spain). Aerobiologia 18, 141-151. doi: 10.1023/A:1020652525493

Hajar, L., Khater, C., and Cheddadi, R. (2008). Vegetation changes during the late Pleistocene and Holocene in Lebanon: a pollen record from the Bekaa Valley. Holocene 18, 1089-1099. doi: 10.1177/0959683608095580

Hammer, Ø., Harper, D. A. T., and Ryan, P. D. (2001). PAST: paleontological statistics software package for education and data analysis. Palaeontol. Electron. $4,1-9$.

Jaouadi, S., Lebreton, V., Bout-Roumazeilles, V., Siani, G., Lakhdar, R., Boussoffara, R., et al. (2016). Environmental changes, climate and anthropogenic impact in south-east Tunisia during the last $8 \mathrm{kyr}$. Clim. Past 12, 1339-1359. doi: 10.5194/cp-12-1339-2016

Jensen, C., Vorren, K. D., and Mørkved, B. (2007). Annual pollen accumulation rate (PAR) at the boreal and alpine forest-line of north-western Norway, with special emphasis on Pinus sylvestris and Betula pubescens. Rev. Palaeobot. Palynol. 144, 337-361. doi: 10.1016/j.revpalbo.2006.08.006

Knippertz, P., Christoph, M., and Speth, P. (2003). Long-term precipitation variability in Morocco and the link to the large-scale circulation in recent and future climates. Meteorol. Atmos. Phys. 83, 67-88. doi: $10.1007 /$ s00703-002-0561-y

Lamb, H. F., Damblon, F., and Maxted, R. W. (1991). Human impact on the vegetation of the Middle Atlas, Morocco, during the last 5000 years. J. Biogeogr. 18, 519-532. doi: $10.2307 / 2845688$

Lamb, H. F., Eicher, U., and Switsur, V. R. (1989). An 18,000-year record of vegetation, lake-level and climatic change from Tigalmamine, Middle Atlas, Morocco. J. Biogeogr. 16, 65-74. doi: 10.2307/2845311

Lamb, H. F., Gasse, F., and Benkaddour, A. (1995). Relation between century-scale Holocene arid intervals in tropical and temperate zones. Nature 373, 134-137. doi: $10.1038 / 373134 \mathrm{a} 0$

Lamb, H. F., and van der Kaars, S. (1995). Vegetational response to Holocene climatic change: pollen and palaeolimnological data from the Middle Atlas, Morocco. Holocene 5, 400-408. doi: 10.1177/095968369500500402

Lamb, H., Roberts, N., Leng, M., Barker, P., Benkaddour, A., and van der Kaars, S. (1999). Lake evolution in a semi-arid montane environment: response to catchment change and hydroclimatic variation. J. Paleolimnol. 21, 325-343. doi: 10.1023/A:1008099602205

Lelieveld, J., Proestos, Y., Hadjinicolaou, P., Tanarhte, M., Tyrlis, E., and Zittis, G. (2016). Strongly increasing heat extremes in the Middle East and North Africa (MENA) in the 21st century. Clim. Change 137, 245-260. doi: 10.1007/s10584-016-1665-6

Linares, J. C., Pazo-Sarria, R., Taïqui, L., Camarero, J. J., Ochoa, V., Lechuga, V., et al. (2012). Efectos de las tendencias climáticas y la degradación del hábitat sobre el decaimiento de los cedrales (Cedrus atlantica) del norte de Marruecos. Revista Ecosistemas 21, 7-14. doi: 10.7818/ECOS.2012.21-3.02

Linares, J. C., Taïqui, L., and Camarero, J. J. (2011). Increasing drought sensitivity and decline of Atlas cedar (Cedrus atlantica) in the Moroccan Middle Atlas forests. Forests 2, 777-796. doi: 10.3390/f2030777

Linstädter, A., and Zielhofer, C. (2010). Regional fire history shows abrupt responses of Mediterranean ecosystems to centennial-scale climate change (Olea-Pistacia woodlands, NE Morocco). J. Arid Environ. 74, 101-110. doi: 10.1016/j.jaridenv.2009.07.006

Magri, D. (1994). Late-Quaternary changes of plant biomass as recorded by pollen-stratigraphical data: a discussion of the problem at Valle di Castiglione, Italy. Rev. Palaeobot. Palynol. 81, 313-325. doi: 10.1016/0034-6667(94) 90115-5

Markgraf, V. (1980). Pollen dispersal in a mountain area. Grana 19, 127-146. doi: 10.1080/00173138009424995

Mauri, A., Davis, B. A. S., Collins, P. M., and Kaplan, J. O. (2015). The climate of Europe during the Holocene: a gridded pollen-based reconstruction and its multi-proxy evaluation. Q. Sci. Rev. 112, 109-127. doi: 10.1016/j.quascirev.2015.01.013

Mayewski, P. A., Rohling, E. E., Stager, J. C., Karlén, W., Maasch, K. A., Meeker, L. D., et al. (2004). Holocene climate variability. Q. Res. 62, 243-255. doi: 10.1016/j.yqres.2004.07.001

McGregor, H. V., Dupont, L., Stuut, J. B. W., and Kuhlmann, H. (2009). Vegetation change, goats, and religion: a 2000-year history of land use in southern Morocco. Q. Sci. Rev. 28, 1434-1448. doi: 10.1016/j.quascirev.2009. 02.012

Medail, F., and Quezel, P. (1997). Hot-spots analysis for conservation of plant biodiversity in the Mediterranean Basin. Ann. Missouri Bot. Garden 84, 112-127. doi: $10.2307 / 2399957$

Menjour, F., Amraoui, F., and Remmal, T. (2016). "Assessment of the spatio-temporal evolution of Aguelmam Sidi Ali Lake using multitemporal Landsat Imagery (Middle Atlas-Morocco)," in 6th International Conference on Cartography and GIS, eds T. Bandrova and M. Konecny (Sofia: Bulgarian Cartographic Association), 588-597.

Moore, P. D., Webb, J. A., and Collison, M. E. (1991). Pollen Analysis. Oxford: Blackwell Scientific Publications.

Morales-Molino, C., Tinner, W., García-Antón, M., and Colombaroli, D. (2017). The historical demise of Pinus nigra forests in the Northern Iberian Plateau (south-western Europe). J. Ecol. 105, 634-646. doi: 10.1111/1365-2745.12702

Moritz, C., and Agudo, R. (2013). The future of species under climate change: resilience or decline? Science 341, 504-508. doi: 10.1126/science. 1237190

Nogués-Bravo, D., Araújo, M. B., Errea, M. P., and Martinez-Rica, J. P. (2007). Exposure of global mountain systems to climate warming during the 21st Century. Glob. Environ. Change 17, 420-428. doi: 10.1016/j.gloenvcha.2006.11.007

Nourelbait, M., Rhoujjati, A., Benkaddour, A., Carré, M., Eynaud, F., Martinez, P., et al. (2016). Climate change and ecosystems dynamics over the last 6000 years in the Middle Atlas, Morocco. Clim. Past 12, 1029-1042. doi: 10.5194/cp-12-1029-2016

Nourelbait, M., Rhoujjati, A., Eynaud, F., Benkaddour, A., Dezileau, L., Wainer, K., et al. (2014). An 18 000-year pollen and sedimentary record from the cedar forests of the Middle Atlas, Morocco. J. Q. Sci. 29, 423-432. doi: $10.1002 /$ jqs. 2708

Ozenda, P. (1975). Sur les etages de vegetation dans les montagnes du bassin mediterraneen. Docum. Cartogr. Écol. 16, 1-32.

Parmesan, C. (2006). Ecological and evolutionary responses to recent climate change. Annu. Rev. Ecol. Evol. Syst. 37, 637-669. doi: 10.1146/annurev.ecolsys.37.091305.110100 
Peguero-Pina, J. J., Sancho-Knapik, D., Barrón, E., Camarero, J. J., Vilagrosa, A., and Gil-Pelegrín, E. (2014). Morphological and physiological divergences within Quercus ilex support the existence of different ecotypes depending on climatic dryness. Ann. Bot. 114, 301-313 doi: 10.1093/aob/mcu108

Prentice, I. C. (1985). Pollen representation, source area, and basin size: toward a unified theory of pollen analysis. Q. Res. 23, 76-86. doi: 10.1016/0033-5894(85)90073-0

Reddad, H., Etabaai, I., Rhoujjati, A., Taieb, M., Thevenon, F., and Damnati, B. (2013). Fire activity in North West Africa during the last 30,000 cal years BP inferred from a charcoal record from Lake Ifrah (Middle atlas-Morocco): climatic implications. J. Afr. Earth Sci. 84, 47-53. doi: 10.1016/j.jafrearsci.2013.03.007

Reille, M. (1976). Analyse pollinique de sédiments postglaciaires dans le MoyenAtlas et le Haut- Atlas marocains: premiers résultats. Ecol. Mediterr. 2, 153-170.

Reille, M. (1992). Pollen et Spores d'Europe et d'Afrique du Nord. Marseille: Laboratoire de Botanique historique et Palynologie.

Reimer, P. J., Bard, E., Bayliss, A., Beck, J. W., Blackwell, P. G., Ramsey, C. B., et al. (2013). IntCal13 and Marine13 radiocarbon age calibration curves 0-50,000 years cal BP. Radiocarbon 55, 1869-1887. doi: 10.2458/azu_js_rc.55.16947

Renssen, H., Seppä, H., Heiri, O., Roche, D. M., Goosse, H., and Fichefet, T. (2009). The spatial and temporal complexity of the Holocene thermal maximum. Nat. Geosci. 2, 411-414. doi: 10.1038/ngeo513

Rhanem, M. (2009). L'alfa (Stipa tenacissima L.) dans la plaine de Midelt (haut bassin versant de la Moulouya, Maroc)-Éléments de climatologie. Physio-Géo. $3,1-20$.

Rhanem, M. (2011). Aridification du climat régional et remontée de la limite inférieure du cèdre de l'Atlas (Cedrus atlantica Manetti) aux confins de la plaine de Midelt (Maroc). Physio-Géo 5, 143-165.

Rhoujjati, A., Cheddadi, R., Taïeb, M., Baali, A., and Ortu, E. (2010). Environmental changes over the past c. 29,000 years in the Middle Atlas (Morocco): a record from Lake Ifrah. J. Arid Environ. 74, 737-745. doi: $10.1016 /$ j.jaridenv.2009.09.006

Rohling, E. J., and Pälike, H. (2005). Centennial-scale climate cooling with a sudden cold event around 8,200 years ago. Nature 434, 975-979. doi: $10.1038 /$ nature 03421

Rubiales, J. M., Morales-Molino, C., Álvarez, S. G., and García-Antón, M. (2012). Negative responses of highland pines to anthropogenic activities in inland Spain: a palaeoecological perspective. Veg. Hist. Archaeobot. 21, 397-412. doi: $10.1007 / \mathrm{s} 00334-011-0330-2$

Rull, V., López-Sáez, J. A., and Vegas-Vilarrúbia, T. (2008). Contribution of non-pollen palynomorphs to the paleolimnological study of a high-altitude Andean lake (Laguna Verde Alta, Venezuela). J. Paleolimnol. 40, 399-411. doi: 10.1007/s10933-007-9169-z

Samartin, S., Heiri, O., Joos, F., Renssen, H., Franke, J., Brönnimann, S., et al. (2017). Warm Mediterranean Mid Holocene summers inferred from fossil midge assemblages. Nat. Geosci. 10, 207-212. doi: 10.1038/ngeo2891
Sayad, A., Chakiri, S., Martin, C., Bejjaji, Z., and Echarfaoui, H. (2011). Effet des conditions climatiques sur le niveau du lac Sidi Ali (Moyen Atlas, Maroc). Physio-Géo. 5, 251-268.

Schwörer, C., Gavin, D. G., Walker, I. R., and Hu, F. S. (2017). Holocene tree line changes in the Canadian Cordillera are controlled by climate and topography. J. Biogeogr. 44, 1148-1159. doi: 10.1111/jbi.12904

Seppä, H., and Hicks, S. (2006). Integration of modern and past pollen accumulation rate (PAR) records across the arctic tree-line: a method for more precise vegetation reconstructions. Q. Sci. Rev. 25, 1501-1516. doi: $10.1016 /$ j.quascirev.2005.12.002

Stockmarr, J. (1971). Tablets with spores used in absolute pollen analysis. Pollen Spores 13, 615-621.

Tabel, J., Khater, C., Rhoujjati, A., Dezileau, L., Bouimetarhan, I., Carre, M., et al. (2016). Environmental changes over the past 25000 years in the southern Middle Atlas, Morocco. J. Q. Sci. 31, 93-102. doi: 10.1002/jqs.2841

Tinner, W., Colombaroli, D., Heiri, O., Henne, P. D., Steinacher, M., Untenecker, J., et al. (2013). The past ecology of Abies alba provides new perspectives on future responses of silver fir forests to global warming. Ecol. Monogr. 83, 419-439. doi: 10.1890/12-2231.1

Vaz, M., Pereira, J. S., Gazarini, L. C., David, T. S., David, J. S., Rodrigues, A., et al. (2010). Drought-induced photosynthetic inhibition and autumn recovery in two Mediterranean oak species (Quercus ilex and Quercus suber). Tree Physiol. 30, 946-956. doi: 10.1093/treephys/tpq044

Wanner, H., Solomina, O., Grosjean, M., Ritz, S. P., and Jetel, M. (2011). Structure and origin of Holocene cold events. Q. Sci. Rev. 30, 3109-3123. doi: 10.1016/j.quascirev.2011.07.010

Zielhofer, C., Fletcher, W. J., Mischke, S., De Batist, M., Campbell, J. F., Joannin, S., et al. (2017a). Atlantic forcing of Western Mediterranean winter rain minima during the last 12,000 years. Q. Sci. Rev. 157, 29-51. doi: 10.1016/j.quascirev.2016.11.037

Zielhofer, C., von Suchodoletz, H., Fletcher, W. J., Schneider, B., Dietze, E., Schlegel, M., et al. (2017b). Millennial-scale fluctuations in Saharan dust supply across the decline of the African Humid Period. Q. Sci. Rev. 171, 119-135. doi: 10.1016/j.quascirev.2017.07.010

Conflict of Interest Statement: The authors declare that the research was conducted in the absence of any commercial or financial relationships that could be construed as a potential conflict of interest.

Copyright (๑) 2017 Campbell, Fletcher, Joannin, Hughes, Rhanem and Zielhofer. This is an open-access article distributed under the terms of the Creative Commons Attribution License (CC BY). The use, distribution or reproduction in other forums is permitted, provided the original author(s) or licensor are credited and that the original publication in this journal is cited, in accordance with accepted academic practice. No use, distribution or reproduction is permitted which does not comply with these terms. 